\title{
Natural and experimental high-pressure, shock-produced terrestrial and extraterrestrial materials
}

\author{
Masaaki Miyahara ${ }^{\text {** }}$, Naotaka Tomioka ${ }^{2}$ and Luca Bindi ${ }^{3}$
}

\begin{abstract}
Hypervelocity impacts are among the fundamental phenomena occurring during the evolution of the solar system and are characterized by instantaneous ultrahigh pressure and temperature. Varied physicochemical changes have occurred in the building blocks of celestial bodies under such extreme conditions. The constituent material has transformed into a denser form, a high-pressure polymorph. The high-pressure polymorph is also thought to be the constituent of the deep Earth's interior. Hence, experiments using a high-pressure and temperature generating apparatus have been conducted to clarify its crystal structure, pressure-temperature stability range, and transformation mechanisms. A natural high-pressure polymorph (mineral) is found from terrestrial and extraterrestrial rocks that experienced a hypervelocity impact. Mineralogists and planetary scientists have investigated high-pressure minerals in meteorites and rocks near terrestrial craters over a half-century. Here, we report brief reviews about the experiments producing high-pressure polymorphs and then summarize the research histories of high-pressure minerals occurring in shocked meteorites and rocks near terrestrial craters. Finally, some implications of high-pressure minerals found in impactinduced shocked rocks are also mentioned.
\end{abstract}

Keywords: High-pressure mineral, Shock metamorphism, Meteorite, Impact crater

\section{Introduction}

High-pressure minerals have considered the major constituents of the Earth's deep interior, and their physicochemical properties and transformation mechanisms are essential parameters to understand the structure and dynamics of the Earth's depths. Therefore, mineral physicists who work on high-pressure minerals have been making long-standing efforts to clarify the structural changes and phase equilibria using a multianvil apparatus and a laser-heated diamond anvil cell (LHDAC).

Mineralogists and planetary scientists have tried to find high-pressure minerals in meteorites (Fig. 1) and rocks near terrestrial impact craters because we cannot

\footnotetext{
*Correspondence: miyahara@hiroshima-u.ac.jp

${ }^{1}$ Graduate School of Advanced Science and Engineering, Hiroshima

University, Higashihiroshima 739-8526, Japan

Full list of author information is available at the end of the article
}

get high-pressure minerals directly from the Earth's deep interior except for inclusions in diamond crystals (Moore and Gurney 1985; Walter et al. 2011; Pearson et al. 2014) and mantle xenoliths (Collerson et al. 2000). Indeed, the first high-pressure mineral was discovered in a terrestrial impact crater; Chao et al. (1960) found a high-pressure polymorph of $\mathrm{SiO}_{2}$, then named coesite, from the Barringer crater in the USA, and Chao et al. (1962) then found a second $\mathrm{SiO}_{2}$ polymorph, named stishovite, from the same crater (Fig. 2). A. El Goresy (1934-2019), who was a world-leading mineral physicist/meteoriticist working on shock metamorphism, discovered a new allotropic form of carbon, named chaoite in memory of the contributions of E. C. T. Chao for his pioneer works, from the Rice crater in Germany (El Goresy and Donnay 1968).

The first discovery of a high-pressure mineral from a meteorite is the $(\mathrm{Mg}, \mathrm{Fe})_{2} \mathrm{SiO}_{4}$ ringwoodite (Binns et al. $1969)$, and the second and third cases are the (Mg,Fe) 
$\mathrm{SiO}_{3}$ majorite (Smith and Mason 1970) and wadsleyite (Price et al. 1983) (Fig. 2; Table 1). High-pressure minerals in shocked rocks are heterogeneously distributed on a micrometer scale, and their crystal sizes are nano-micrometers across. In most cases, the occurrence of high-pressure minerals in shocked meteorites is restricted in the vicinity of shock-induced melt veins (shock-melt veins) and melt pockets up to several millimeters in width (Fig. 1). Technical difficulties on the characterization of such minute crystals shrunk further efforts to search for new high-pressure minerals and caused a long stagnation since the 1970s (Fig. 2).

The breakthrough was brought by the introduction of a transmission electron microscope equipped with an X-ray energy-dispersive spectrometer (TEM-EDS) (Fig. 2). TEM-EDS analysis enables textural observations, crystallographic scrutinies, and chemical composition analyses at nano-microscales. A. El Goresy, M. Chen, T. Sharp, and their colleagues showed a beautiful ringwoodite grain having dense stacking faults in shock-melt veins of the Sixiangkou L6 ordinary chondrite by TEM (Chen et al. 1996). Subsequently, Sharp et al. (1997) and Tomioka and Fujino (1997) almost simultaneously found natural $(\mathrm{Mg}, \mathrm{Fe}) \mathrm{SiO}_{3}$ with the ilmenite structure (named akimotoite later) from the Tenham L6 ordinary chondrite by using TEM-EDS analysis. In the same contribution, these authors also reported an electron diffraction pattern of $(\mathrm{Mg}, \mathrm{Fe}) \mathrm{SiO}_{3}$ with the perovskite structure (named bridgmanite later by another set of authors) along with akimotoite (Tomioka and Fujino 1997). A. El Goresy and his colleagues also found a silica mineral with scrutinyite $\left(\alpha-\mathrm{PbO}_{2}\right)$-type structure from the shergottite Shergotty by TEM-EDS analysis (Sharp et al. 1999). We cannot directly observe a high-pressure polymorph of $(\mathrm{Mg}, \mathrm{Fe})_{2} \mathrm{SiO}_{4}$, poirierite, without high-resolution TEM analysis because of its complex and ultrafine crystals within the host olivine (Tomioka et al. 2021).

The second breakthrough was caused by the introduction of in situ analysis techniques: (i) micro-fabrication and -pickup technology, a focused ion beam (FIB) system, (ii) focused synchrotron X-ray diffraction (sXRD) techniques, and iii) electron backscattered diffraction (EBSD) analysis. An ultrathin film (thickness: 100 nm) had been prepared for TEM-EDS analysis and was prepared conventionally by Ar-ion-milling and ultramicrotomy. However, a target containing high-pressure minerals for TEM-EDS analysis is submicron-sized. We must minimize the destruction of a valuable meteorite sample during the pickup process of such a small portion. The introduction of an FIB system overcame the difficulty (e.g., Miyahara et al. 2008; Wirth 2009). sXRD analysis, which uses a high-power X-ray beam, is a powerful tool to identify the crystal structure of submicron-sized material. SEM-EBSD analysis can identify minerals in meteorites on the surface of a polished petrographic section in a short time without sample destruction. The number of new high-pressure minerals exponentially increased since the introduction of these new analysis techniques (Fig. 2). Furthermore, the application of laser microRaman spectroscopy makes the characterization of highpressure minerals in shocked rocks very rapid and easy. By the means of a 1- $\mu \mathrm{m}$ diameter laser beam, such a technique allows the identification of fine-grained minerals in polished petrographic thin sections within several $10 \mathrm{~s}$, thus enabling systematic investigations of high-pressure minerals (e.g., Ohtani et al. 2004; Miyahara et al. 2020). However, meticulous interpretation of a Raman shift is necessary for identification because some high-pressure minerals have similar Raman shifts (e.g., Baziotis et al. 2018). Cross-check by another analysis technique should be carried out when necessary.

Here we review the syntheses of high-pressure minerals and their discoveries in natural samples in the last six decades. In this review, a high-pressure mineral is termed as a mineral that is stable only at the Earth's mantle pressure conditions (above $\sim 1 \mathrm{GPa}$ ) as listed in Table 1 . Their formation mechanisms, representative phase diagrams, and typical diagnostic Raman spectra are summarized in Gasparik (2003) and Tomioka and Miyahara (2017). Concise but comprehensive introductions of shock-produced highpressure minerals are also available in Sharp and DeCarli (2006), Morrison and Hazen (2021) and on our database website (https://sites.google.com/site/highpmineral).

\section{High-pressure minerals in meteorites}

\subsection{High-pressure polymorphs of $(\mathrm{Mg}, \mathrm{Fe})_{2} \mathrm{SiO}_{4}$}

Olivine $\left[(\mathrm{Mg}, \mathrm{Fe})_{2} \mathrm{SiO}_{4}\right]$ is one of the major constituents of meteorites, and its high-pressure polymorphs are found from ordinary chondrites, lunar meteorites, Martian meteorites, and carbonaceous chondrites (Tomioka and Miyahara 2017). High-pressure polymorphs for olivine ( $\alpha$-phase), spinelloid-type $(\mathrm{Mg}, \mathrm{Fe})_{2} \mathrm{SiO}_{4}$ ( $\beta$-phase), spinel-type $\quad(\mathrm{Mg}, \mathrm{Fe})_{2} \mathrm{SiO}_{4} \quad$ ( $\gamma$-phase), spinelloid-type

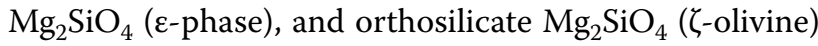
are reported. The fayalite components of olivine for $\mathrm{H}$, L, and LL group ordinary chondrites are 16-23, 23-26, and $27-32 \mathrm{~mol} \%$, respectively (Weisberg et al. 2006). The fayalite components of olivine in Martian meteorites and carbonaceous chondrites are widespread and higher than ordinary chondrites and lunar meteorites. Hence, Fe-rich high-pressure polymorphs of $(\mathrm{Mg}, \mathrm{Fe})_{2} \mathrm{SiO}_{4}$ dominate in Martian meteorites and carbonaceous chondrites compared with other meteorites. 


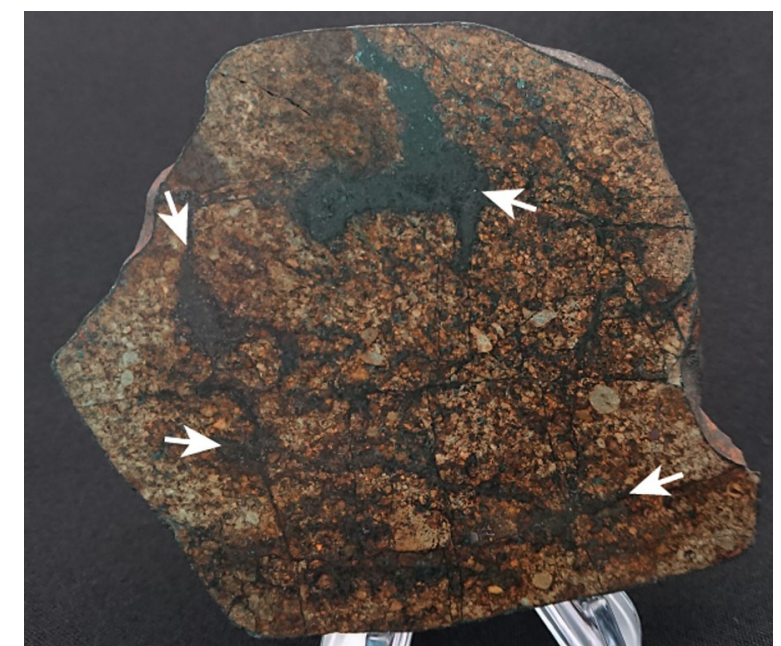

Fig. 1 A heavily shocked meteorite (The Monze L6 ordinary chondrite). Black-colored veins (white-colored arrows) are shock-melt veins

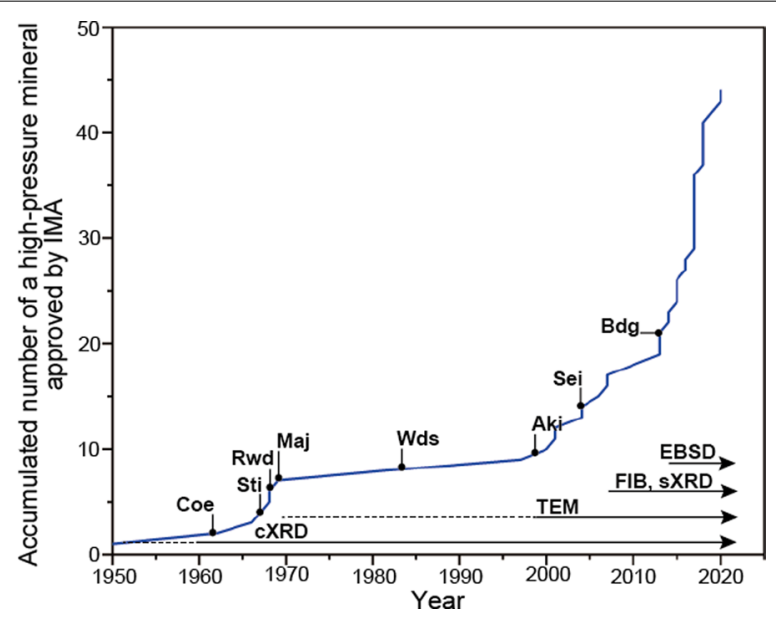

Fig. 2 The accumulated number of a new high-pressure mineral by year. The discovery of major minerals is shown in the figure. The introduction years of instruments are also shown. Coe: coesite, Sti: stishovite, Rwd: ringwoodite, Wds: wadsleyite, Maj: majorite, Aki: akimotoite, Bdg: bridgmanite, Sei: seifertite. CXRD: conventional $X$-ray diffraction, TEM: transmission electron microscopy, FIB: focused ion beam, sXRD: synchrotron X-ray diffraction, EBSD: electron backscattered diffraction

\subsection{1 $\beta$ - $(\mathrm{Mg}, \mathrm{Fe})_{2} \mathrm{SiO}_{4}$ : Wadsleyite-asimowite}

Ringwood and Major (1966a) conducted high-pressure experiments in the $\mathrm{Mg}_{2} \mathrm{SiO}_{4}-\mathrm{Fe}_{2} \mathrm{SiO}_{4}$ system using the early-stage Bridgman anvil apparatus at 12-20 GPa and $900{ }^{\circ} \mathrm{C}$ to confirm an olivine-spinel transition. $\mathrm{Mg}_{2} \mathrm{SiO}_{4}$ with a spinelloid structure was first reported as a distorted spinel phase in their experimental samples based on X-ray diffraction (XRD) analysis (Ringwood and
Major 1966a). The crystal structure of the distorted spinel phase was better studied four years later and regarded as a new orthorhombic phase $\left(\beta-\mathrm{Mg}_{2} \mathrm{SiO}_{4}\right) 8 \%$ denser than forsterite (Ringwood and Major 1970).

Natural $\beta-\mathrm{Mg}_{2} \mathrm{SiO}_{4}$ with a quench texture was discovered in the black-colored shock-melt veins of the Tenham and Peace River L6 ordinary chondrites by TEM observations (Putnis and Price 1979). The mineral was named wadsleyite after A. D. Wadsley (Price et al. 1983). Later systematic investigations revealed that, in most cases, wadsleyites in ordinary chondrites have crystallized from a shock-produced chondritic melt simultaneously transformed by a solid-state reaction from olivine entrained in the chondritic melt (Miyahara et al. 2020). The former always coexists with low-Ca pyroxene, and the latter occurs at the grain boundaries or fractures in the olivine grains (Fig. 3).

Although pure $\mathrm{Fe}_{2} \mathrm{SiO}_{4}$ with a spinelloid structure $\left(\beta-\mathrm{Fe}_{2} \mathrm{SiO}_{4}\right)$ has not been synthesized, Finger et al. (1993) obtained single wadsleyite crystals with $40 \%$ of fayalite component at $15.2 \mathrm{GPa}$ and $1973 \mathrm{~K}$. A mineral with Fe dominance over $\mathrm{Mg}$ in the octahedral sites was found as inclusion in the shock-induced Fe-Ni droplets of the Suizhou L6 ordinary chondrite and the Quebrada Chimborazo 001 CB carbonaceous chondrite and was named asimowite after P. D. Asimow (Bindi et al. 2019).

\subsection{2 $\gamma$-(Mg, $\mathrm{Fe})_{2} \mathrm{SiO}_{4}$ : Ringwoodite-ahrensite}

The $\mathrm{Mg}_{2} \mathrm{SiO}_{4}-\mathrm{Fe}_{2} \mathrm{SiO}_{4}$ solid solution with a spinel structure ( $\gamma$-phase) in the compositional range of $\mathrm{Fe} /$ $(\mathrm{Mg}+\mathrm{Fe})=0.15-0.75$ was reported experimentally by Ringwood and Major (1966a). As for the end-member composition, $\gamma-\mathrm{Fe}_{2} \mathrm{SiO}_{4}$ was first synthesized at $3 \mathrm{GPa}$, $660{ }^{\circ} \mathrm{C}$ by a squeezer apparatus (Ringwood 1958a), while the convincing evidence for $\gamma-\mathrm{Mg}_{2} \mathrm{SiO}_{4}$ was first reported later via synthesis at $25 \mathrm{GPa}$ and $1000{ }^{\circ} \mathrm{C}$ by a Kawai-type multianvil apparatus (Ito et al. 1974). $\mathrm{Mg}_{2} \mathrm{SiO}_{4}$ with a spinel structure $\left(\gamma-\mathrm{Mg}_{2} \mathrm{SiO}_{4}\right)$ was also obtained first experimentally by Ringwood and Major (1966a). Binns et al. (1969) found purple/blue isotropic grains in the shockmelt vein of the Tenham L6 ordinary chondrite by optical microscopic observations and obtained a powder XRD pattern from the grains. The latter could be assigned to $\gamma-\mathrm{Mg}_{2} \mathrm{SiO}_{4}$ and the mineral was named ringwoodite after A. E. Ringwood (Binns et al. 1969). Jeanloz (1979) claimed that ringwoodite is merely a complex mineral aggregate, misidentified as a spinel phase. Against the criticism, Putnis and Price (1979) presented conclusive evidence for the existence of ringwoodite, as they provide a TEM image of a single ringwoodite crystal in the shockmelt vein of the Tenham chondrite.

Most ringwoodite in shocked meteorites is a polycrystalline assemblage (across $<1-2 \mu \mathrm{m}$ ) (Xie and Sharp 2004; 
Table 1 Inventory of high-pressure minerals

\begin{tabular}{|c|c|c|c|c|}
\hline Year" & Mineral name & Structure & Chemistry & References \\
\hline- & Diamond & Diamond & $C$ & Prior to 1960 \\
\hline 1962 & Coesite & Unique monoclinic structure & $\mathrm{SiO}_{2}$ & Chao et al. (1960) \\
\hline 1966 & Lonsdaleite & Wurtzite & C & Frondel and Marvin (1967) \\
\hline 1967 & Stishovite & Rutile & $\mathrm{SiO}_{2}$ & Chao et al. (1962) \\
\hline 1968 & Chaoite & Carbyne & C & El Goresy and Donnay (1968) \\
\hline 1968 & Ringwoodite & Spinel & $\mathrm{Mg}_{2} \mathrm{SiO}_{4}$ & Binns et al. (1969) \\
\hline 1969 & Majorite & Garnet & $\mathrm{MgSiO}_{3}$ & Smith and Mason (1970) \\
\hline 1982 & Wadsleyite & $\beta$-spinelloid & $\mathrm{Mg}_{2} \mathrm{SiO}_{4}$ & Price et al. (1983) \\
\hline 1997 & Akimotoite & Ilmenite & $\mathrm{MgSiO}_{3}$ & Tomioka and Fujino (1999) \\
\hline 2000 & Allabogdanite & $\mathrm{CO}_{2} \mathrm{Si}$ & $(\mathrm{Fe}, \mathrm{Ni})_{2} \mathrm{P}$ & Britvin et al. (2002) \\
\hline 2001 & Tuite & $\mathrm{Ba}_{3}\left(\mathrm{PO}_{4}\right)_{2}$ & $\mathrm{Ca}_{3}\left(\mathrm{PO}_{4}\right)_{2}$ & Xie et al. (2004) \\
\hline 2001 & Reidite & Scheelite & $\mathrm{ZrSiO}_{4}$ & Glass et al. (2002) \\
\hline 2004 & Lingunite & Hollandite & $\mathrm{NaAlSi}_{3} \mathrm{O}_{8}$ & Liu and El Gorsey (2007) \\
\hline 2004 & Seifertite & Scrutinyite & $\mathrm{SiO}_{2}$ & El Goresy et al. (2008) \\
\hline 2006 & Dmitryivanovite & $\mathrm{CaGa}_{2} \mathrm{O}_{4}-\|$ & $\mathrm{CaAl}_{2} \mathrm{O}_{4}$ & Mikouchi et al. (2009) \\
\hline 2007 & Xieite & $\mathrm{CaTi}_{2} \mathrm{O}_{4}$ & $\mathrm{FeCr}_{2} \mathrm{O}_{4}$ & Chen et al. (2008) \\
\hline 2007 & Akaogiite & Baddeleyite & $\mathrm{TiO}_{2}$ & El Goresy et al. (2010) \\
\hline 2010 & Icosahedrite & Icosahedral quasicrystal & $\mathrm{Al}_{63} \mathrm{Cu}_{24} \mathrm{Fe}_{13}$ & Bindi et al. (2011) \\
\hline 2013 & Ahrensite & Spinel & $\mathrm{Fe}_{2} \mathrm{SiO}_{4}$ & Ma et al. (2016) \\
\hline 2013 & Tissintite & Clinopyroxene & $(\mathrm{Ca}, \mathrm{Na}, \mathrm{v}) \mathrm{AlSi}_{2} \mathrm{O}_{6}$ & Ma et al. (2015) \\
\hline 2013 & Liebermannite & Hollandite & $\mathrm{KAISi}_{3} \mathrm{O}_{8}$ & Ma et al. (2018) \\
\hline 2014 & Bridgmanite & Perovskite & $\mathrm{MgSiO}_{3}$ & Tschauner et al. (2014) \\
\hline 2014 & Jeffbenite* & Unique tetragonal structure & $\mathrm{Mg}_{3} \mathrm{Al}_{2} \mathrm{Si}_{3} \mathrm{O}_{12}$ & Nestola et al. (2016) \\
\hline 2015 & Decagonite & Decagonal quasicrystal & $\mathrm{Al}_{71} \mathrm{Ni}_{24} \mathrm{Fe}_{5}$ & Bindi et al. (2015a) \\
\hline 2015 & Riesite & Srilankite-like structure & $\mathrm{TiO}_{2}$ & Tschauner et al. (2020b) \\
\hline 2015 & Zagamiite & Hexagonal barium ferrite & $\mathrm{CaAl}_{2} \mathrm{Si}_{3.5} \mathrm{O}_{11}$ & Ma and Tschauner (2017) \\
\hline 2016 & Hemleyite & Ilmenite & $\mathrm{FeSiO}_{3}$ & Bindi et al. (2017) \\
\hline 2016 & Wangdaodeite & $\mathrm{LiNbO}_{3}$ & $\mathrm{FeTiO}_{3}$ & Xie et al. (2020) \\
\hline 2017 & Stöfflerite & Hollandite & $\mathrm{CaAl}_{2} \mathrm{Si}_{2} \mathrm{O}_{8}$ & Tschauner et al. (2021) \\
\hline 2017 & Vestaite & Schreyerite & $(\mathrm{Ti}, \mathrm{Fe}) \mathrm{Ti}_{4} \mathrm{O}_{9}$ & Pang et al. (2018) \\
\hline 2017 & $\left.|c e-V|\right|^{*}$ & Cuprite-like structure & $\mathrm{H}_{2} \mathrm{O}$ & Tschauner et al. (2018) \\
\hline 2017 & Chenmingite & Harmunite & $\mathrm{FeCr}_{2} \mathrm{O}_{4}$ & Ma et al. (2019b) \\
\hline 2017 & Feiite & $\mathrm{Sr}_{2} \mathrm{Tl}_{2} \mathrm{O}_{5}$ & $\mathrm{Fe}^{2+}{ }_{2}\left(\mathrm{Fe}^{2+} \mathrm{Ti}^{4+}\right) \mathrm{O}_{5}$ & Ma et al. (2021b) \\
\hline 2017 & Liuite & $\mathrm{GdFeO}_{3}$ & $\mathrm{FeTiO}_{3}$ & Ma et al. (2021b) \\
\hline 2017 & Maohokite & Harmunite & $\mathrm{MgFe}_{2} \mathrm{O}_{4}$ & Chen et al. (2019) \\
\hline 2017 & Tschaunerite & $\mathrm{CaTi}_{2} \mathrm{O}_{4}$ & $\left(\mathrm{Fe}^{2+}\right)\left(\mathrm{Fe}^{2+} \mathrm{Ti}^{4+}\right) \mathrm{O}_{4}$ & Ma et al. (2021a) \\
\hline 2018 & Asimowite & $\beta$-spinelloid & $\mathrm{Fe}_{2} \mathrm{SiO}_{4}$ & Bindi et al. (2019) \\
\hline 2018 & Proxidecagonite & Decagonite approximant & $\mathrm{Al}_{34} \mathrm{Ni}_{9} \mathrm{Fe}_{2}$ & Bindi et al. (2018b) \\
\hline 2018 & Donwilhelmsite & Unique hexagonal structure & $\mathrm{CaAl}_{4} \mathrm{Si}_{2} \mathrm{O}_{11}$ & Fritz et al. (2020) \\
\hline 2018 & Poirierite & $\varepsilon$-spinelloid & $\mathrm{Mg}_{2} \mathrm{SiO}_{4}$ & Tomioka et al. (2021) \\
\hline 2018 & Breyite $^{*}$ & Walstromite & $\mathrm{CaSiO}_{3}$ & Brenker et al. (2021) \\
\hline 2019 & Hiroseite & Perovskite & $\mathrm{FeSiO}_{3}$ & Bindi et al. (2020c) \\
\hline 2020 & Davemaoite* & Perovskite & $\mathrm{CaSiO}_{3}$ & Tschauner et al. (2020a) \\
\hline 2020 & Elgoresyite & Unique monoclinic structure & $\left(\mathrm{Mg}_{5} \mathrm{Si}_{2}\right) \mathrm{O}_{9}$ & Bindi et al. (2021) \\
\hline
\end{tabular}

\# Year for new mineral-proposal (IMA No.) to the Commission on New Minerals, Nomenclature and Classification (CNMNC) of the International Mineralogical Association (IMA)

* High-pressure minerals occur only as inclusions in diamond but are not produced by shock metamorphism 
Xie et al. 2006; Chen et al. 2007; Miyahara et al. 2010; Sharp et al. 2015) (Fig. 4a). Some olivine-ringwoodite (or ahrensite) assemblage composed of a ringwoodite (Rwd) (or ahrensite (Ahr)) sheet with a specific crystallographic orientation to preserve the close-packed oxygen layers of both structures-(100) $)_{\mathrm{Ol}} / /\{111\}_{\mathrm{Rwd} / \mathrm{Ahr}}$-is also found in an olivine $(\mathrm{Ol})$ grain in contact with a shock-melt vein of the Yamato (Y)-791384 L6 ordinary chondrite (Miyahara et al. 2010) (Fig. 4b) or in the shock region of a grain of the Khatyrka CV3 carbonaceous chondrite (Hollister et al. 2014).

$\gamma-\mathrm{Ni}_{2} \mathrm{GeO}_{4}$ as an analog of $\mathrm{Fe}_{2} \mathrm{SiO}_{4}$ with a spinel structure $\left(\gamma-\mathrm{Fe}_{2} \mathrm{SiO}_{4}\right)$ was synthesized by Ringwood (1958b). Natural $\gamma-\mathrm{Fe}_{2} \mathrm{SiO}_{4}$ was discovered in the shock-melt vein of the Umbarger L6 ordinary chondrite by TEM observations (Xie et al. 2002b). Later, it was also found from the melt-pocket of the olivine-phyric shergottite Tissint by a combined powder XRD and EBSD analysis and named ahrensite after T. Ahrens (Ma et al. 2016). Like ringwoodite, most ahrensite grains are also polycrystalline assemblages, and some olivine-ahrensite assemblages consist of an ahrensite sheet with a specific crystallographic orientation, namely $(001)_{\mathrm{Ol}} / /\{111\}_{\mathrm{Ahr}}$ (Miyahara et al. 2016). Unlike wadsleyite, most ringwoodite-ahrensite have formed through a solid-solid-state transformation in ordinary chondrites and Martian meteorites (Walton et al. 2014; Ma et al. 2016; Miyahara et al. 2016, 2020; Tomioka and Miyahara 2017). In contrast, some ringwoodites in ordinary chondrites have formed from olivine melt or chondritic melt (Xie et al. 2002b; Miyahara et al. 2008, 2009, 2020). Ringwoodite crystallized from a chondritic melt has a dendritic texture (Fig. 4c).

An interesting point is that ringwoodite-ahrensite exhibits the normal spinel structure, with $\mathrm{Mg}(\mathrm{Fe})$ in the octahedral A site and $\mathrm{Si}$ in the tetrahedral $\mathrm{B}$ site. Through A and B site-disorder, the inverse spinel has four-coordinated A cations and the six-coordinated site hosts a mixture of A and B cations. This process affects the density and impedance contrast across the boundaries in the transition zone and seismic-wave velocities in this portion of the Earth. Bindi et al. (2018a) reported the first synthesis at high pressure $(20 \mathrm{GPa})$ and temperature $\left(1600{ }^{\circ} \mathrm{C}\right)$ of a Cr-bearing ringwoodite with a completely inverse-spinel structure. The chemical, structural, and computational analysis confirmed the stability of inverse ringwoodite. The degree of inversion in these minerals is crucial, as discussed by Ma et al. (2019c), because it could influence the inferred conditions of the meteorite during shock-melt cooling.

When an oceanic plate subducts along a trench into the Earth's deep interior, hydrous minerals such as clay minerals and hydroxides are transported into the Earth's depths, resulting in the formation of dense hydrous minerals. Many kinds of hydrous high-pressure polymorphs such as $\delta$-AlOOH have been synthesized through high-pressure and -temperature experiments (e.g., Ohira et al. 2014; Bindi et al. 2020d). High-pressure experiments prove that nominal anhydrous ringwoodite and wadsleyite can also contain a small amount of water in their structures $\left(<2-3 \mathrm{wt} . \% \mathrm{H}_{2} \mathrm{O}\right)$ (e.g., Kohlstedt et al. 1996; Inoue et al. 1998).

A natural hydrous ringwoodite $\left(>1.4 \mathrm{wt}\right.$.\% of $\left.\mathrm{H}_{2} \mathrm{O}\right)$ was found as an inclusion in terrestrial diamond (Pearson et al. 2014). A hydrous ringwoodite $\left(<1132 \mathrm{ppm}_{2} \mathrm{O}\right)$ is also found near the melt-pocket of the shergottite Tissint (Hallis et al. 2017). Mars explorations by rovers and landers indicate that water has existed extensively on the subsurface of Mars (e.g., Bandfield 2007). Some impact events might occur under hydrous conditions. The shergottites NWA 7397 and 10416 have evidence for both shock metamorphism and aqueous alteration (Herd et al. 2016; Yoshida et al. 2021). Hydrous high-pressure minerals may have been overlooked in shocked meteorites.

\subsection{3 $\varepsilon-\mathrm{Mg}_{2} \mathrm{SiO}_{4}$ : Poirierite}

Based on the topological analyses of the crystal structures of the olivine polymorphs in shocked meteorites, shear mechanisms without long-range ionic diffusion are posited to promote their polymorphic transformations. The transformation model also predicted the possible occurrence of an intermediate spinelloid structure ( $\varepsilon$-phase) (Madon and Poirier 1983). After the prediction over three decades, the $\varepsilon$-phase was found as metastable intergrowth within ringwoodite grains in the shock-melt vein of the Tenham L6 ordinary chondrite by meticulous high-resolution (HR)-TEM observations (Tomioka and Okuchi 2017). The $\varepsilon$-phase was also found within ringwoodite and wadsleyite grains from the Suizhou L6 and Miami H5 ordinary chondrites, respectively. Single-crystal XRD analysis of the $\varepsilon$-phase in the Suizhou L6 ordinary chondrite, as well as results of firstprinciples' calculations, confirmed that the $\varepsilon$-phase has an orthorhombic unit cell with the smallest dimensions among the preexisting spinelloid structures, and this phase was named poirierite after J.-P. Poirier (Tomioka et al. 2021) (Fig. 5). The topotaxial intergrowths of poirierite with wadsleyite/ringwoodite in shocked chondrites support the idea proposed by Madon and Poirier (1983) where poirierite is a way point in the shear transformations between olivine and wadsleyite/ringwoodite (e.g., olivine becomes ringwoodite via poirierite).

\subsection{4 ל-olivine}

$\zeta$-olivine was found in the black-colored shocked-olivine in the chassignite Northwest Africa (NWA) 2737 and lherzolitic shergottite NWA 1950 (Beck et al. 2006; 


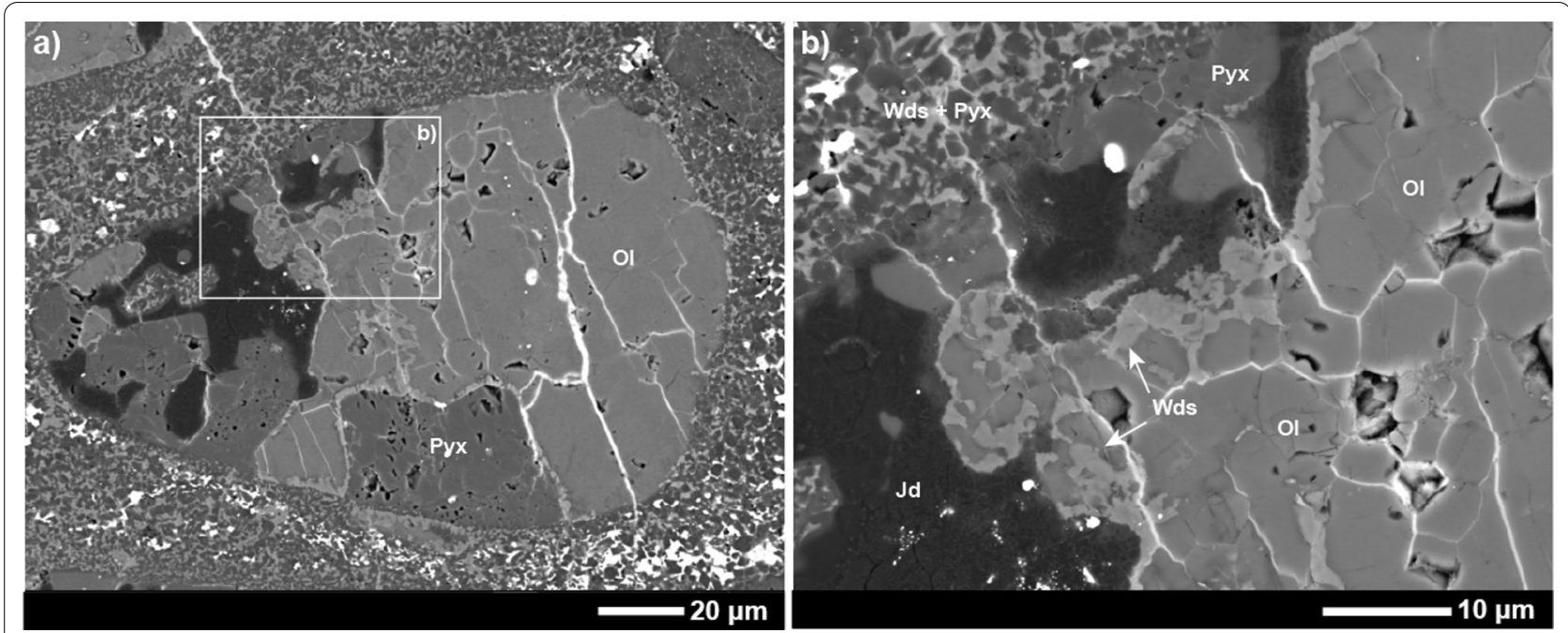

Fig. 3 Backscattered electron (BSE) images of wadsleyite. a A chondritic fragment in the shock-melt vein of Yamato (Y) 000973 L5 ordinary chondrite. $\mathbf{b}$ A high-magnification image of a white-colored box in $\mathbf{a}$. A part of olivine in the fragment has been replaced with polycrystalline wadsleyite. The matrix of the shock-melt vein consists of wadsleyite and low-Ca pyroxene. Ol: olivine, Pyx: Low-Ca pyroxene, Wds: wadsleyite, Jd: jadeite

van de Moortèle et al. 2007). Based on HRTEM observations and first-principles' calculations, the $\zeta$-olivine consists of quasi ideally close-packed oxygen sublattice with disordered cation sites and is regarded as a metastable high-pressure form of $\alpha-(\mathrm{Mg}, \mathrm{Fe})_{2} \mathrm{SiO}_{4}$ produced at high-pressure and relatively low-temperature conditions (Guyot and Reynard 1992; Beck et al. 2006; van de Moortèle et al. 2007). A mineral name has not been given to the $\zeta$-olivine. Takenouchi et al. (2019) reproduced the black-colored shocked-olivine that potentially contains the $\zeta$-phase by shock recovery experiments.

\subsubsection{High-pressure dissociation of $(\mathrm{Mg}, \mathrm{Fe})_{2} \mathrm{SiO}_{4}$}

Phase equilibrium diagram in the system $\mathrm{Mg}_{2} \mathrm{SiO}_{4}-\mathrm{Fe}_{2} \mathrm{SiO}_{4}$ predicts that olivine dissociates into bridgmanite + magnesiowüstite (+stishovite) around 23-25 GPa (Ito and Takahashi 1989), although the dissociation reaction depends on temperature and chemical composition. Miyahara et al. (2011b) found evidence for the dissociation reaction in olivine grains in contact with the shock-melt vein of the olivine-phyric shergottite Dar al Gani (DaG) 735. Granular bridgmanite + magnesiowüstite (Fig. 6a) and lamellar bridgmanite + magnesiowüstite (Fig. 6b) are found in the dissociated olivine grains (with bridgmanite almost vitrified). In most cases, Martian meteorites are heavily shocked compared with ordinary chondrites (e.g., El Goresy et al. 2013; Miyahara et al. 2020). Hence, the high-pressure dissociation of olivine is found mainly in shocked Martian meteorites (Fritz and Greshake 2009; Walton et al. 2014; Miyahara et al. 2019). On the other hand, Bindi et al. (2020c) found
Fe-rich silicate perovskite (hiroseite) as the dissociation products of olivine in the Suizhou chondrite L6 ordinary chondrite. High-pressure experiments suggest that olivine melts incongruently into magnesiowüstite and liquid above $8 \mathrm{GPa}$ and $2100{ }^{\circ} \mathrm{C}$ (Kato et al. 1998; Ohtani et al. 1998). Natural dissociation of olivine by incongruent melting is found from the Kamargaon L6 ordinary chondrite and Apollo 15 regolith breccia (Tiwari et al. 2021; Satta 2021).

\subsection{High-pressure polymorphs of $(\mathrm{Mg}, \mathrm{Fe}, \mathrm{Ca}) \mathrm{SiO}_{3}$ 2.2.1 ( $\mathrm{Mg}, \mathrm{Fe}) \mathrm{SiO}_{3}-\mathrm{Mg}_{3} \mathrm{Al}_{2} \mathrm{Si}_{3} \mathrm{O}_{12}$ : Majorite-pyrope}

The pyroxene is the second major constituent of chondritic meteorites and the Earth's upper mantle. Because of the four main end-member components of pyroxenes (enstatite: $\mathrm{MgSiO}_{3}$, ferrosilite: $\mathrm{FeSiO}_{3}$, diopside: $\mathrm{CaMgSi}_{2} \mathrm{O}_{6}$, and hedenbergite: $\mathrm{CaFeSi}_{2} \mathrm{O}_{6}$ ), the pressure-temperature phase equilibria of pyroxene are more complicated than that of olivine. A natural high-pressure polymorph of the $(\mathrm{Mg}, \mathrm{Fe}) \mathrm{SiO}_{3}$ pyroxene was first discovered in ordinary chondrites. Mason et al. (1968) discovered aggregates with an olivine composition in the Coorara L6 ordinary chondrite using powder XRD and identified their crystal structure as a garnet structure. The garnet composition was initially misidentified because of overlaps of their neighboring ringwoodite grains. A more careful examination showed that their actual chemical composition is close to $(\mathrm{Mg}, \mathrm{Fe}) \mathrm{SiO}_{3}$ (Smith and Mason 1970). Two years before the discovery, the mineral was also synthesized from glass with an Al-bearing $\mathrm{MgSiO}_{3}$ composition at $20 \mathrm{GPa}$ and $\sim 900{ }^{\circ} \mathrm{C}$ (Ringwood 

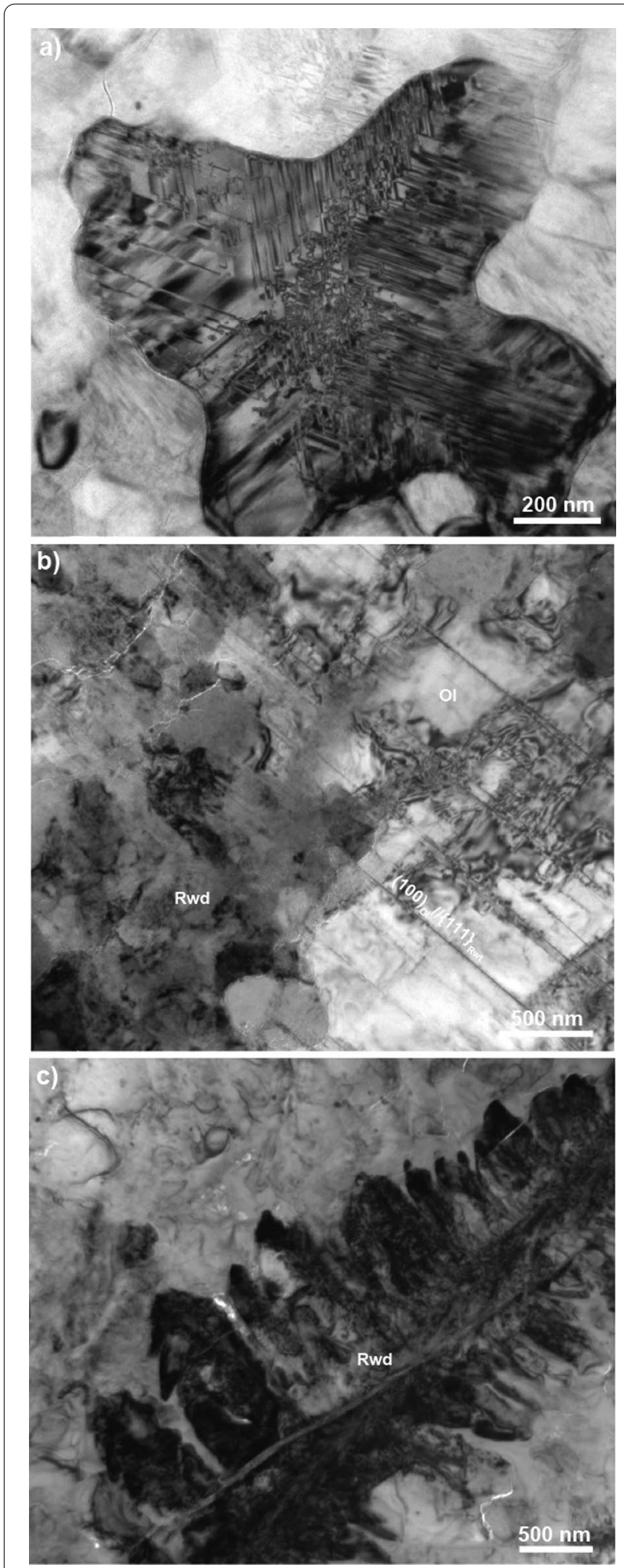

Fig. 4 Bright-field (BF)-TEM images of ringwoodite. a A ringwoodite crystal with a dense stacking fault in the Y-790729 L6 ordinary chondrite. $\mathbf{b}$ An olivine grain replaced with ringwoodite in the Y-791384 L6 ordinary chondrite. A part of the olivine grain in contact with the shock-melt vein is replaced with polycrystalline ringwoodite. Also, thin layers of ringwoodite occur in the olivine grain. The (100) of olivine is parallel with the $\{111\}$ of ringwoodite. $\mathbf{A}$ ringwoodite crystal with a dendritic texture in the Y-74445 L6 ordinary chondrite. Ol: olivine, Rwd: ringwoodite

and Major 1966b). Generally, garnet has only aluminum in its oxygen 6-coordinated sites, while the newly found garnet has a unique characteristic when the structure has $\mathrm{Si}>3$ atoms per formula unit. Indeed, by the Tschermak substitution $\left(2 \mathrm{Al}^{3+} \Leftrightarrow \mathrm{Mg}^{2+}+\mathrm{Si}^{4+}\right)$ in the octahedral sites on the $\mathrm{MgSiO}_{3}-\mathrm{Mg}_{3} \mathrm{Al}_{2} \mathrm{Si}_{3} \mathrm{O}_{12}$ (pyrope) join, we can find octahedral silicon in this structure, which is symptomatic of a very high-pressure regime. The new highpressure mineral found in Coorara was named majorite (Smith and Mason 1970) after A. Major. Al-rich majorite is one of the dominant phases in the matrices of shockmelt veins (e.g., Chen et al. 1996; Miyahara et al. 2020). According to the phase diagram of the Allende CV3 carbonaceous chondrite, Al-rich majorite is thought to have crystallized as a liquidus phase from chondritic melt in the pressure range of 14-26 GPa (Agee et al. 1995; Chen et al. 1996).

Al-rich majorite has a cubic symmetry as usual for silicate garnets, while almost Al-poor/free majorite in the system $\mathrm{MgSiO}_{3}-\mathrm{FeSiO}_{3}$ has a tetragonal distorted symmetry caused by the ordering of $\mathrm{Mg}$ and $\mathrm{Si}$ in the octahedral sites (e.g., Kato and Kumazawa 1985; Angel et al. 1989; Heinemann et al. 1997; Nakatsuka et al. 1999; Tomioka et al. 2002). Natural Ca-rich tetragonal majorite as a dissociation product of subcalsic pyroxene was found in the host-rock fragments in shock-melt veins in the Tenham L6 ordinary chondrite (Xie and Sharp 2007; Tomioka et al. 2016). Polycrystalline low-Ca tetragonal majorite was also found in the same chondrite (Fig. 7) (Tomioka et al. 2016). Following a comparison between the degrees of cation ordering in synthetic and natural majorites, the cooling rate of shock-melt veins during shock metamorphism was constrained to be $10^{3}{ }^{\circ} \mathrm{C} / \mathrm{s}$ (Tomioka et al. 2002, 2016).

Majorite, which was formed by melt crystallization and solid-state transformation, has been reported in many chondrites and Martian meteorites (shergottite) (Tomioka and Miyahara 2017). As for terrestrial impact 


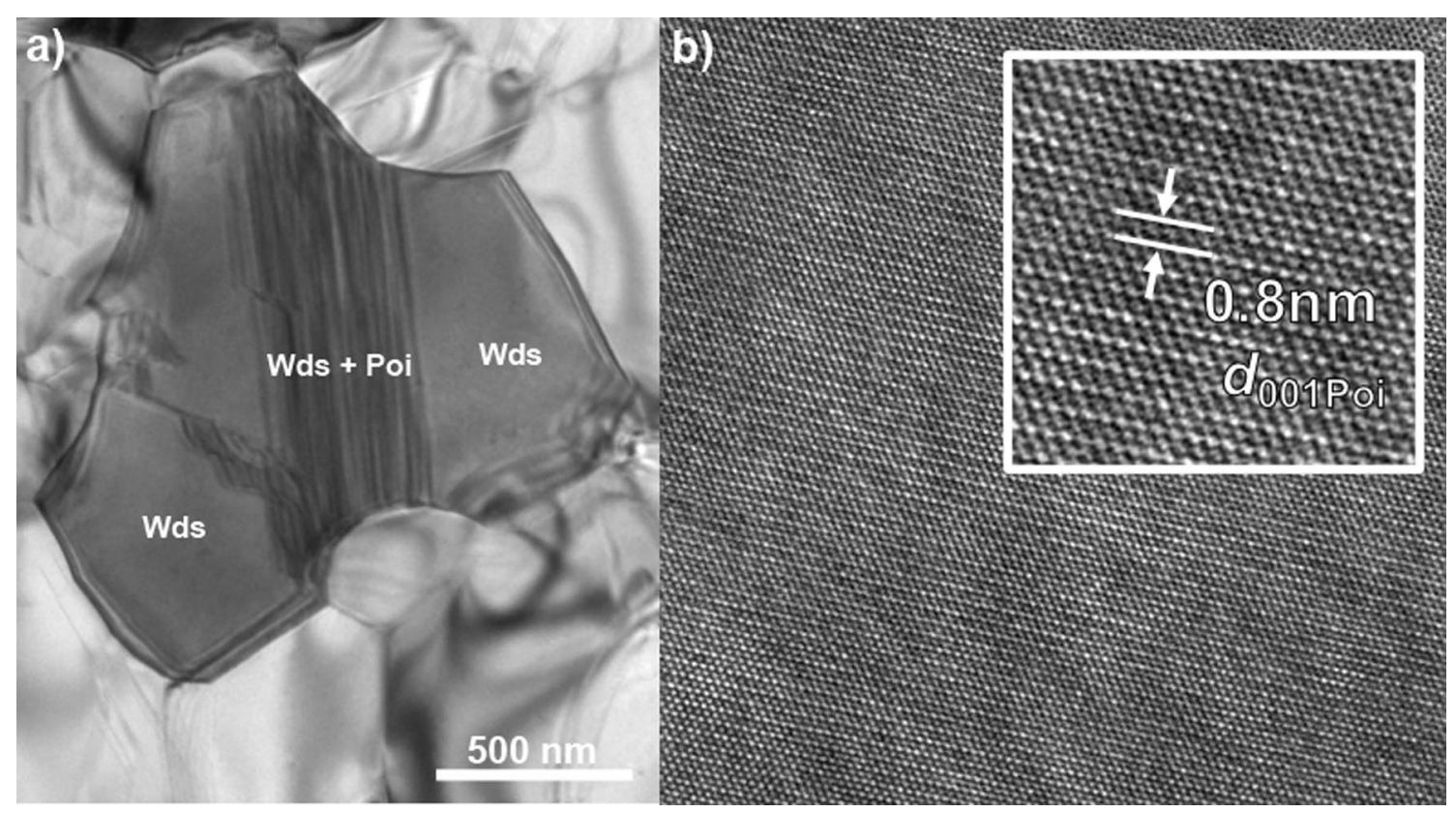

Fig. 5 TEM images of poirierite in the Miami H5 ordinary chondrite. a BF-TEM image of a wadsleyite grain partly replaced by poirierite. $\mathbf{b}$ High-resolution (HR) TEM image of poirierite. Lattice fringes with $0.8 \mathrm{~nm}$ spacings correspond to $d_{001}$. Wds: wadsleyite, Poi: poirierite

structure, the Ries crater also yielded Al-rich majorites with various amounts of $\mathrm{Na}, \mathrm{Fe}, \mathrm{K}, \mathrm{Ca}$, and Fe in shocked amphibolite (Stähle et al. 2010, 2017). Majorite was crystallized from amphibolite melt or chlorite-rich melt induced by an impact.

\subsection{2 $\mathrm{MgSiO}_{3}-\mathrm{FeSiO}_{3}$ : Akimotoite-hemleyite}

Trigonal $\mathrm{MgSiO}_{3}$ phase with the ilmenite structure phase was synthesized at $17.5-27.5 \mathrm{GPa}$ and $1000-1400{ }^{\circ} \mathrm{C}$ by an LHDAC (Liu 1976) following the finding of hexagonal $\mathrm{MgSiO}_{3}$ by Kawai et al. (1974). About 20 years after the syntheses, the natural occurrence of the phase was reported in the shock-melt veins of the Acfer 040 L5-6 and the Tenham L6 ordinary chondrites based on TEM observations (Sharp et al. 1997; Tomioka and Fujino 1997). The matrix of the shock-melt veins in Acfer 040 consists mainly of $\mathrm{MgSiO}_{3}$-rich amorphous grains $\left(\sim 2 \mu \mathrm{m}\right.$ in size), ringwoodite, and $\mathrm{MgSiO}_{3}$-ilmenite. The $\mathrm{MgSiO}_{3}$-ilmenite occurs as plate-like grains and contains considerable amounts of the $\mathrm{Na}_{2} \mathrm{O}, \mathrm{Al}_{2} \mathrm{O}_{3}$, and $\mathrm{FeO}$ components (Sharp et al. 1997), while the $\mathrm{MgSiO}_{3}$-rich amorphous material contains significant amounts of $\mathrm{Na}_{2} \mathrm{O}, \mathrm{Al}_{2} \mathrm{O}_{3}, \mathrm{CaO}$, and $\mathrm{FeO}$. The assemblages and chemical compositions of high-pressure minerals suggest that they have crystallized from shock-induced melt over 26 GPa (Sharp et al. 1997). In Tenham, clinoenstatite $\left[(\mathrm{Mg}, \mathrm{Fe}) \mathrm{SiO}_{3}\right]$, fragments of the host rock entrained in the shock-melt veins, is associated with aggregates of submicron-sized grains and no other minerals in their interstices. Their chemical composition is identical to that of the host clinoenstatite (Tomioka and Fujino 1997) (Fig. 8). The ilmenite phase is thought to have formed directly from the host clinoenstatite without melting. The $\mathrm{MgSiO}_{3}$-ilmenite was named akimotoite after S. Akimoto (Tomioka and Fujino 1999). Akimotoite has been found in chondrites and shergottites (Xie and Sharp 2004; Imae and Ikeda 2010; Tomioka and Miyahara 2017), whereas they have not been reported in impact craters.

Recently, the Fe-rich ilmenite with $\mathrm{Fe} /(\mathrm{Mg}+\mathrm{Fe})=0.56$ was also discovered in an unmelted portion of the heavily shocked L6 ordinary chondrite Suizhou associated with olivine, clinoenstatite, and Fe-bearing pyroxene (Bindi et al. 2017). The occurrence suggests that the new phase formed by a Fe-rich clinoenstatite-formed by the thermal metamorphism in its parent body-was subsequently shock-transformed to Fe-rich akimotoite. The mineral was named hemleyite after R. J. Hemley (Bindi et al. 2017). So far, the $\mathrm{FeSiO}_{3}$ solubility into akimotoite increases up to $\sim 10 \mathrm{~mol} \%$ with increasing pressure from 20 to $25 \mathrm{GPa}$ at $1100{ }^{\circ} \mathrm{C}$ based on a phase equilibrium study (Ito and Yamada 1982), whereas at the $\mathrm{FeSiO}_{3}$ content above $10 \mathrm{~mol} \%$, bridgmanite and majorite are stable rather than akimotoite at a higher pressure and lower temperature, respectively (Ohtani et al. 1991). Therefore, hemleyite would be metastably formed during a short pressure and temperature excursion in the shock event. 

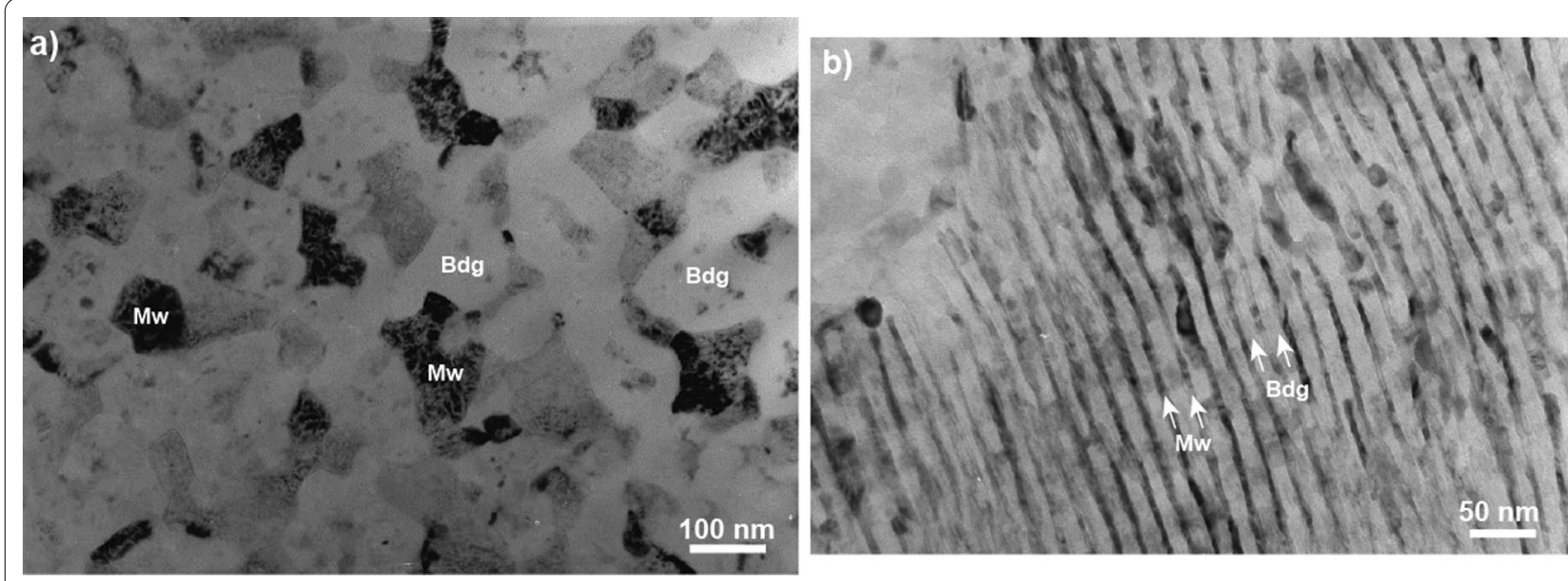

Fig. 6 BF-TEM images of dissociated olivine in the shergottite DaG 735. a Granular bridgmanite + magnesiowüstite, b lamellar bridgmanite + magnesiowüstite. Most bridgmanite have been vitrified. Bdg: bridgmanite, Mw: magnesiowüstite

\subsection{3 $\mathrm{MgSiO}_{3}-\mathrm{FeSiO}_{3}$ : bridgmanite-hiroseite}

Silicate perovskite has been first synthesized from pyrope at $30 \mathrm{GPa}$ and above $800{ }^{\circ} \mathrm{C}$ in the $\mathrm{Al}$-bearing system by an LHDAC (Liu 1974). Subsequently, pure $\mathrm{MgSiO}_{3}$ perovskite was synthesized at $30 \mathrm{GPa}$ and $\sim 1000{ }^{\circ} \mathrm{C}$ by an LHDAC (Liu 1975) and $28 \mathrm{GPa}$ and $\sim 1000{ }^{\circ} \mathrm{C}$ by a Kawai-type multianvil apparatus (Ito and Matsui 1978). These phases have an orthorhombic symmetry with the same structure as perovskite $\left(\mathrm{CaTiO}_{3}\right)$. The mineral is of particular interest to geophysicists because the phase occupies $\sim 77$ vol\% of the Earth's lower mantle (Irifune 1993).

In nature, $(\mathrm{Mg}, \mathrm{Fe}) \mathrm{SiO}_{3}$ grains $(\sim 0.3 \mu \mathrm{m}$ in size $)$ adjacent to a clinoenstatite grain were identified in the Tenham L6 ordinary chondrite to be crystalline as a perovskite-structure phase using TEM (Tomioka and Fujino 1997). The perovskite phase has the same chemical composition as clinoenstatite in the host rock, which is considered to have formed in a solid phase transition as well as akimotoite in the Tenham chondrite. Fine-scale intergrowth of $(\mathrm{Mg}, \mathrm{Fe}) \mathrm{SiO}_{3}$-perovskite and magnesiowüstite, as post-ringwoodite dissociation products of olivine, were also found in the shergottite DaG 735 (Miyahara et al. 2011b). The presented TEM works did not give full crystallographic data on the perovskite phase because of its large susceptibility to electron beam radiation. However, synchrotron X-ray micro-diffraction finally gave data to determine the unit cell of $(\mathrm{Mg}, \mathrm{Fe}) \mathrm{SiO}_{3}$-perovskite in the Tenham chondrite. The mineral was named bridgmanite after P. W. Bridgman (Tschauner et al. 2014).

Recently, a Fe-rich silicate perovskite phase with $\mathrm{Fe} /$ $(\mathrm{Mg}+\mathrm{Fe})=0.59$ was discovered in a shock-melt vein in the Suizhou chondrite L6 ordinary chondrite based on XRD, TEM, and micro-Raman spectroscopy (Bindi

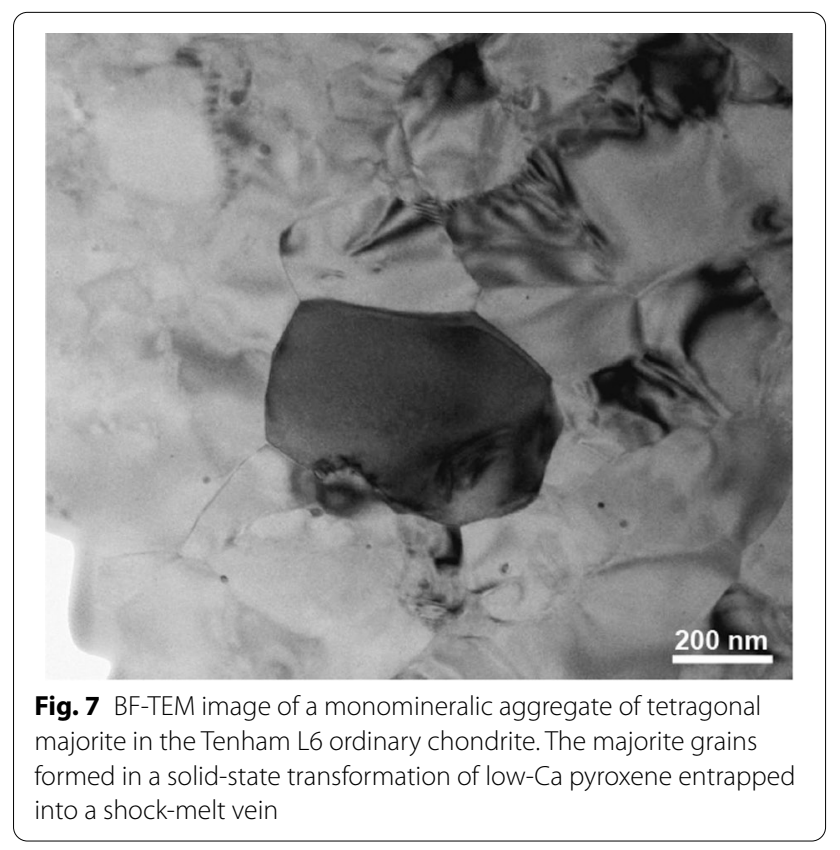

et al. 2020c). Interestingly, Fe nanoparticles less than $100 \mathrm{~nm}$ in size were found embedded in the host perovskite phase that has both ferric and ferrous iron. That is the first evidence for a subsolidus charge disproportionation reaction in natural high-pressure minerals: $3 \mathrm{Fe}^{2+} \rightarrow \mathrm{Fe}^{0}+2 \mathrm{Fe}^{3+}$. The mineral was named hiroseite after K. Hirose (Bindi et al. 2020c). So far, bridgmanite has not been found in terrestrial impact craters.

It is noteworthy that a bridgmanite-like mineral was discovered in the Acfer 094 carbonaceous chondrite (ungrouped C2). The mineral is $\sim 300 \mathrm{~nm}$ in size and has an oxygen isotope anomaly (Vollmer et al. 2007). Electron 


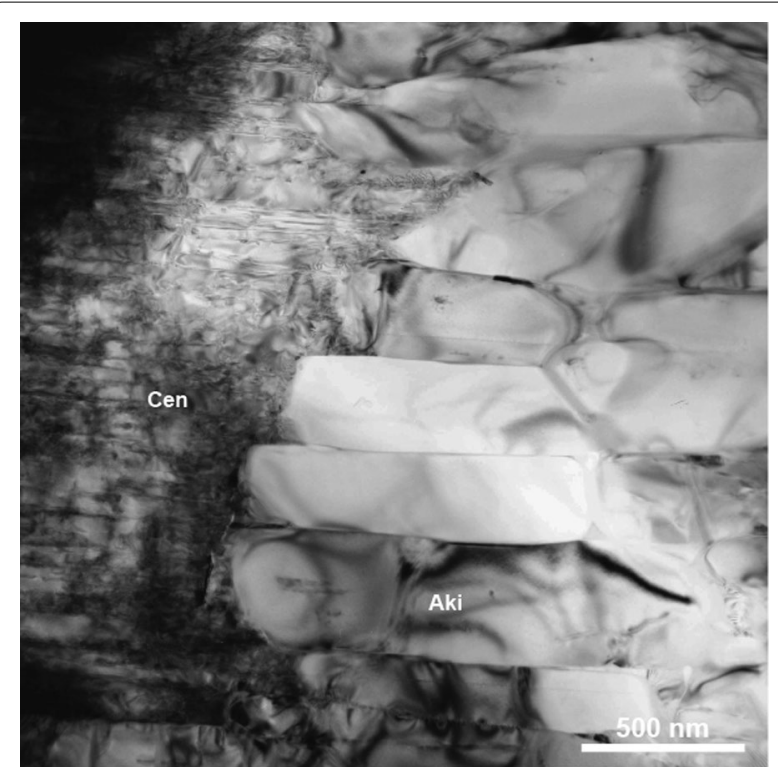

Fig. 8 BF-TEM image of akimotoite (Aki) in the Tenham L6 ordinary chondrite. The akimotoite grains formed in a solid-state transformation from low-Ca pyroxene (clinoenstatite: Cen) with (100) twin lamellae in the host rock entrapped into a shock-melt vein

diffraction patterns of the mineral indicate a superstructure of the orthorhombic perovskite structure. A possible explanation of the formation process of the novel mineral is that presolar $\mathrm{MgSiO}_{3}$-pyroxene particles floating in interstellar space have transformed into the perovskitelike phase by interstellar shock waves before incorporation into its parent body.

$\mathrm{CaSiO}_{3}$ with the perovskite structure was also confirmed at $16 \mathrm{GPa}$ and $1500{ }^{\circ} \mathrm{C}$ by an LHDAC (Liu and Ringwood 1975). It is not an atmospheric pressure quenchable phase but vitrified during decompression. As for shocked meteorites, $\mathrm{CaSiO}_{3}$-rich amorphous phase coexisting with $\mathrm{Ca}$-rich majorite was reported in a shock-melt vein of the Y-75100 H6 ordinary chondrite (Tomioka and Kimura 2003). The diopside in the host rock would have initially dissociated into $\mathrm{CaSiO}_{3}$ with the perovskite structure plus Ca-rich majorite during prograde shock metamorphism, and then, the perovskite phase became amorphous during the subsequent retrograde stage. Crystalline $\mathrm{CaSiO}_{3}$ perovskite with an orthorhombic cell was found in a terrestrial environment as inclusion in a super-deep diamond from South African Cullinan kimberlite (Nestola et al. 2018). More recently, cubic $\mathrm{CaSiO}_{3}$ perovskite was also reported in a diamond from Botswanan Orapa kimberlite, and then named davemaoite after H.-K. Mao (Tschauner et al. 2020a).

\subsubsection{Other high-pressure minerals with the pyroxene compositions}

The $\mathrm{MgSiO}_{3}$ component has various pyroxene-structure polymorphs with different crystal symmetries caused by configurational changes of the $\mathrm{SiO}_{4}$ tetrahedral chains at high pressures and temperatures: low-temperature clinoenstatite (space group $P 2_{1} / c$ ), orthoenstatite $(P b c a)$, protoenstatite $(\mathrm{Pbcn})$, high-temperature clinoenstatite $(C 2 / c)$, and high-pressure clinoenstatite $(C 2 / c)$ (Gasparik 1990). High-pressure clinoenstatite was found by in situ XRD study at pressures above $\sim 7 \mathrm{GPa}$ (Angel et al. 1992; Shinmei et al. 1999); however, it cannot be recovered to the ambient condition as it inverts to low-temperature clinoenstatite during decompression. Recently, evidence for high-pressure clinoenstatite was found in the shockmelt vein of the Grove Mountains 022,115 L6 ordinary chondrite by HRTEM (Guo et al. 2020). The occurrence of high-pressure clinoenstatite embedded in amorphous silicate and associated with majorite and ringwoodite suggests that the assemblage was initially crystallized as majorite at $20-23 \mathrm{GPa}$ and over $1800{ }^{\circ} \mathrm{C}$ and was subsequently back-transformed to high-pressure clinoenstatite during retrograde shock metamorphism. High-pressure clinoenstatite would have been metastably frozen because of extremely rapid cooling (Guo et al. 2020).

A novel $\mathrm{Fe}$, $\mathrm{Al}$-bearing $\mathrm{MgSiO}_{3}$-rich phase was reported in the silicate glass matrix of shock-melt veins in Tenham L6 ordinary chondrite by TEM (Xie et al. 2011). The mineral has an acicular morphology $(\leq 0.5 \mu \mathrm{m}$ in length) and its electron diffraction pattern indicates an olivine structure. A possible explanation to reconcile the discrepancy between the olivine structure and the pyroxene stoichiometry of the phase is the presence of cation vacancies at the $M$ site in the olivine structure. The estimated density of $3.32 \mathrm{~g} / \mathrm{cm}^{3}$ is slightly larger than those of olivine and pyroxenes; therefore, the mineral would have metastably crystallized from chondritic melt under high pressure during rapid cooling (Xie et al. 2011).

\subsection{High-pressure polymorphs of feldspar \\ 2.3.1 Jadeite + silica}

Albitic plagioclase is one of the major constituents of equilibrated ordinary chondrites. Albite $\left(\mathrm{NaAlSi}_{3} \mathrm{O}_{8}\right)$ dissociates into jadeite $\left(\mathrm{NaAlSi}_{2} \mathrm{O}_{6}\right)+$ quartz $\left(\mathrm{SiO}_{2}\right)$, jadeite + coesite $\left(\mathrm{SiO}_{2}\right)$, and jadeite + stishovite with increasing pressure and temperature (Liu 1978). However, these dissociation products do not occur in the shock-melt veins of equilibrated ordinary chondrites. In most cases, jadeite solely occurs in originally plagioclase grains (e.g., Ohtani et al. 2004; Ozawa et al. 2009; 
Miyahara et al. 2013b). Jadeite shows several kinds of crystal habits, namely, dendritic, granular, stringlike, and polycrystalline (Ozawa et al. 2009; Miyahara et al. 2020), which depend on the formation processes. Even in the large-scale shock metamorphism, pressure duration is not long enough ( $<$ several seconds) to form coesite or stishovite along with jadeite because of its sluggish nucleation (Kubo et al. 2010). However, the jadeite + coesite assemblage has replaced an albitic plagioclase grain in some ordinary chondrites (Miyahara et al. 2017, 2020). On the other hand, Ma et al. (2020) propose that highly defective jadeite $(\mathrm{Na}, \mathrm{Ca}, v)(\mathrm{Al}, \mathrm{Si}) \mathrm{Si}_{2} \mathrm{O}_{6}$ ( $v=$ vacancy) with excess silicon has formed in an albitic plagioclase grain of some ordinary chondrites.

\subsubsection{Tissintite}

Plagioclase in Martian and lunar meteorites is richer in anorthite components compared with equilibrated ordinary chondrites (Papike 2018). Tissintite is clinopyroxene-type $(\mathrm{Ca}, \mathrm{Na}, v) \mathrm{AlSi}_{2} \mathrm{O}_{6}$ and found in an anorthite grain in contact with the melt-pocket of the shergottite Tissint (Ma et al. 2015). Tissintite was synthesized from amorphous plagioclase under 6-8 GPa and 1273-1623 K (Rucks et al. 2018). Most tissintite grains in shocked meteorites show a dendritic or spherulitic texture, suggesting rapid crystallization from anorthitic melt (Fig. 9).

\subsubsection{Lingunite-Stöfflerite-Liebermannite}

Hollandite-type $\mathrm{KAlSi}_{3} \mathrm{O}_{8}$ was synthesized first at $12 \mathrm{GPa}$ and $900{ }^{\circ} \mathrm{C}$ by Ringwood et al. (1967). Also, Liu (1978) synthesized hollandite-type $\mathrm{NaAlSi}_{3} \mathrm{O}_{8}$ above $20 \mathrm{GPa}$ at $\sim 1000{ }^{\circ} \mathrm{C}$ using an LHDAC. In contrast, subsequent experimental works in the system $\mathrm{NaAlSi}_{3} \mathrm{O}_{8}-\mathrm{KAlSi}_{3} \mathrm{O}_{8}$ reported that the hollandite phase is stable only in K-rich composition $(\mathrm{Na} /(\mathrm{Na}+\mathrm{K}):<\sim 0.4)$, while calcium ferrite $\left(\mathrm{CaFe}_{2} \mathrm{O}_{4}\right)$-type $\mathrm{NaAlSiO}_{4}+$ stishovite appears at Na-rich composition $(\mathrm{Na} /(\mathrm{Na}+\mathrm{K}):>\sim 0.4)$ above $\sim 20 \mathrm{GPa}$ and $1000{ }^{\circ} \mathrm{C}$ (Yagi et al. 1994; Liu 2006). This discrepancy was reconciled by a recent transformation kinetics study that clarified that hollandite-type $\mathrm{NaAlSi}_{3} \mathrm{O}_{8}$ is a metastable phase crystallized from amorphous plagioclase glass (Kubo et al. 2017).

Hollandite-type $\mathrm{NaAlSi}_{3} \mathrm{O}_{8}$ replacing albitic feldspar was found in the shock-melt veins of the Sixiangkou and Tenham L6 ordinary chondrites (Gillet et al. 2000; Tomioka et al. 2000; Xie and Sharp 2004). A small amount of K-feldspar has also been found in some Martian and lunar meteorites. Hollandite-type $\mathrm{KAISi}_{3} \mathrm{O}_{8}$ was found in the melt-pocket of the basaltic shergottite Zagami (Langenhorst and Poirier 2000). Hollandite-type $\mathrm{NaAlSi}_{3} \mathrm{O}_{8}$ and $\mathrm{KAlSi}_{3} \mathrm{O}_{8}$ were named lingunite after $\mathrm{L}$.
G. Liu (Liu and El Gorsey 2007) and libermannite after R. C. Liebermann (Ma et al. 2018), respectively. Lingunite was also found from the doleritic rocks of Lockne impact structure (Agarwal et al. 2016). Hollandite-type $\mathrm{CaAl}_{2} \mathrm{Si}_{2} \mathrm{O}_{8}$ has yet to be synthesized but was recently found in a melt-pocket of the basaltic shergottite NWA 856 and named stöfflerite after D. Stöffler (Tschauner et al. 2021).

\subsubsection{Donwilhelmsite-zagamiite}

A calcium aluminum silicate phase $\left(\mathrm{CaAl}_{4} \mathrm{Si}_{2} \mathrm{O}_{11}\right)$ was synthesized by Irifune et al. (1994) and tentatively named the $\mathrm{Ca}-\mathrm{Al}-\mathrm{Si}$-rich (CAS) phase. Its crystal structure with the $\mathrm{CaAl}_{4} \mathrm{Si}_{2} \mathrm{O}_{11}$ composition was determined to be of the hexagonal $\mathrm{BaFe}_{2} \mathrm{O}_{4}$-type based on single-crystal XRD (Gautron et al. 1999). A mineral with $\left(\mathrm{Ca}_{\mathrm{x}}, \mathrm{Na}_{1-\mathrm{x}}\right)$ $\mathrm{Al}_{3+\mathrm{x}} \mathrm{Si}_{3-\mathrm{x}} \mathrm{O}_{11}$ composition was discovered in some shergottites such as Zagami and NWA 856 by micro-Raman spectroscopy (Beck et al. 2004; El Goresy et al. 2013). The mineral is intergrown with acicular stishovite grains in melt pockets. A natural CAS phase was also found from the feldspathic lunar meteorite Oued Awlitis 001 and was well characterized by three-dimensional electron diffraction pattern analysis (Fritz et al. 2020). This mineral was named donwilhelmsite after D. E. Wilhelms (Fritz et al. 2020). Ma et al. (2019a) also found a hexagonal $\mathrm{BaFe}_{2} \mathrm{O}_{4}$-type $\mathrm{CaAl}_{2} \mathrm{Si}_{3.5} \mathrm{O}_{11}$ in the melt-pocket of Zagami and NWA 856 and named it zagamiite. Zagamiite is expected to be a crystallization product from a plagioclase-rich melt with some clinopyroxene components because it has small amounts of Fe and $\mathrm{Mg}$ and a substantial deficit of $\mathrm{Na}$ (Ma et al. 2019a).

\subsubsection{Dense plagioclase glass}

Experimentally shocked plagioclase becomes an amorphous phase with a high refractive index without loss of short-range ordering in its structure (Milton and de Carli 1963; Kitamura et al. 1977). The first identification of such a dense plagioclase glass is from the shergottite Shergotty and has been called maskelynite after N. S. Maskelyne (Tschermak 1872). Similar dense plagioclase glass has been then commonly found in strongly shocked chondrites and achondrites (e.g., Stöffler et al. 1986, 1991). The glass almost retains the morphology of the original plagioclase but loses its crystallinity. Therefore, it is easy to be identified by its optical isotropy under a polarizing microscope.

One of the big debates about maskelynite is its formation process. Some maskelynite shows a flowing texture or mixing texture with other melts (schlieren), suggesting that the maskelynite has formed by the quenching of plagioclase shock-induced melt (El Goresy et al. 2013). By contrast, some maskelynite has retained original 


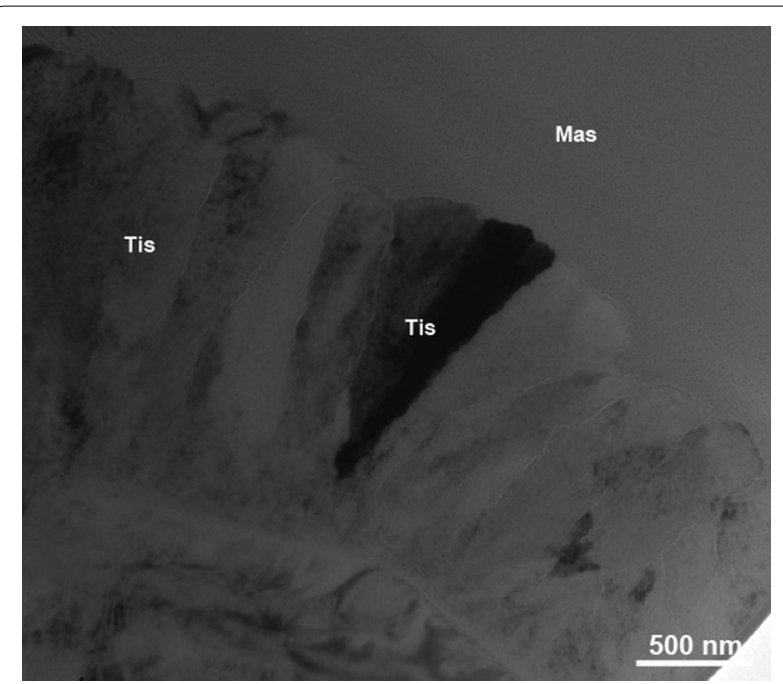

Fig. 9 BF-TEM image of tissintite in the shergottite Tissint. Spherulitic tissintites have occurred in an original plagioclase grain in contact with the melt-pocket of Tissint. The interstices are filled with amorphized plagioclase (probably because of melting). Tis: Tissintite, Mas: maskelynite

compositional zoning, suggesting that the maskelynite has formed through a solid-solid-state phase transformation (Jaret et al. 2015).

Tschermak (1883) originally described that maskelynite has a non-vesicular flow texture resulting from melting and liquid migration followed by solidification. Based on the historical background, only material with evidence for melting like schlieren should be called maskelynite, whereas material without evidence of melting should be called diaplectic plagioclase glass. Normal glass is quenched from a melt which is still liquid after pressure release (Stöffler 1984). In case that the formation process (solid-state amorphization or melting) is not clear, but its high density can be assumed by its higher refractive index than normal plagioclase glass under an optical microscope (Stöffler et al. 1986, 1991), we suggest the term "dense plagioclase glass" instead of "maskelynite" and "diaplectic plagioclase glass" to avoid confusion.

\subsection{High-pressure polymorphs of silica}

The synthesis and naming histories of high-pressure polymorphs of silica, except for seifertite, are mentioned in a later section because their first discoveries are from a terrestrial impact crater. Coesite, stishovite, and seifertite are high-pressure polymorphs of silica. Quartz is rare but cristobalite and tridymite are abundant in meteorites (Papike 2018). Hence, most high-pressure polymorphs of silica have occurred as replacements of cristobalite or tridymite.
As a discovery from a meteorite, Weisberg and Kimura (2010) found coesite in the Gujba CB carbonaceous chondrite for the first time by Raman spectroscopy. Coesite is mainly found in basaltic lunar meteorites and eucrites (Miyahara et al. 2014; Tomioka and Miyahara 2017; Kayama et al. 2018) but very rarely from enstatite chondrite and Martian meteorite (Kimura et al. 2017; Hu et al. 2020). TEM observations revealed that these coesite crystals are granular and always coexist with silica glass or quartz (Miyahara et al. 2013a, 2014) (Fig. 10). Coesite is also found as one of the decomposition products of albitic plagioclase in shocked ordinary chondrites (Miyahara et al. 2017, 2020).

As for stishovite replacing silica minerals, it was discovered from the lunar meteorite Asuka-881757 for the first time (Ohtani et al. 2011). Stishovite crystals are acicular and always coexist with silica glass, the same as coesite (Ohtani et al. 2011; Miyahara et al. 2013a, 2014; Kayama et al. 2018). Stishovite is mainly found in basaltic lunar meteorites, eucrites, and shergottites (Tomioka and Miyahara 2017) and very rarely from carbonaceous chondrite (Bindi et al. 2012) and iron meteorite (Holtstam et al. 2003). Some stishovites have formed through the high-pressure decomposition of plagioclase in some shocked shergottites (Langenhorst and Poirier 2000; Beck et al. 2004; El Goresy et al. 2013). Kaneko et al. (2015) discovered stishovite from regolith breccia Apollo 15,299. This is the first case of a high-pressure mineral being discovered in extraterrestrial rocks by sample return missions.

Scrutinyite $\left(\alpha-\mathrm{PbO}_{2}\right)$-type silica was synthesized in shock recovery experiments of quartz up to $90 \mathrm{GPa}$ (German et al. 1973). Its natural analog was found from the basaltic shergottite Shergotty (Sharp et al. 1999; Dera et al. 2002) and named seifertite after F. Seifert by El Goresy et al. (2008). Seifertite is also found from other shergottites and basaltic lunar meteorites (El Goresy et al. 2013; Miyahara et al. 2013a). In situ XRD studies show that seifertite is stable in the pressure range of 120-260 GPa (Murakami et al. 2003; Kuwayama et al. 2005), while Kubo et al. (2015) clarified that seifertite has metastably formed from cristobalite even above $11 \mathrm{GPa}$. Therefore, seifertite is unlikely an indicator of megabar shock pressures in shergottites and lunar meteorites. Seifertite in backscattered electron images always shows a tweedlike texture, which is one of the diagnostic features for its identification (El Goresy et al. 2008). Like stishovite, seifertite crystals exhibit an acicular morphology and always coexist with silica glass (Miyahara et al. 2013a) (Fig. 11). El Goresy et al. (2000) also found an unnamed post-stishovite phase with the baddeleyite $\left(\mathrm{ZrO}_{2}\right)$-like structure from one shergottite. 


\subsection{Others}

\subsubsection{High-pressure polymorphs of phosphate minerals}

A $\mathrm{Ca}_{3}\left(\mathrm{PO}_{4}\right)_{2}$ mineral with a $\mathrm{Ba}_{3}\left(\mathrm{PO}_{4}\right)_{2}$-structure $\left[\gamma-\mathrm{Ca}_{3}\left(\mathrm{PO}_{4}\right)_{2}\right]$ was synthesized by Murayama et al. (1986). Xie et al. (2002a) reported that merrillite $\left[\mathrm{Ca}_{9} \mathrm{NaMg}\left(\mathrm{PO}_{4}\right)_{7}\right]$ has transformed into the $\gamma-\mathrm{Ca}_{3}\left(\mathrm{PO}_{4}\right)_{2}$ phase in the shock-melt vein of the Suizhou L6 ordinary chondrite. The $\gamma-\mathrm{Ca}_{3}\left(\mathrm{PO}_{4}\right)_{2}$ phase was named tuite after G. Tu (Xie et al. 2004).

\subsubsection{High-pressure polymorphs of chromite}

$\mathrm{CaTi}_{2} \mathrm{O}_{4}$-type $\mathrm{FeCr}_{2} \mathrm{O}_{4}$ phase was synthesized by Chen et al. (2003a), and a natural one was found in the Suizhou L6 ordinary chondrite (Chen et al. 2003b). The $\mathrm{CaTi}_{2} \mathrm{O}_{4}$-type $\mathrm{FeCr}_{2} \mathrm{O}_{4}$ phase was named xieite after $\mathrm{X}$. Xie (Chen et al. 2008). Harmunite $\left(\mathrm{CaFe}_{2} \mathrm{O}_{4}\right)$-type $\mathrm{FeCr}_{2} \mathrm{O}_{4}$ phase was synthesized by Chen et al. (2003a), and a natural one was found in the Suizhou L6 ordinary chondrite (Chen et al. 2003b). The mineral was named chenmingite after M. Chen (Ma et al. 2019b).

\subsubsection{High-pressure polymorphs of other oxides}

$\mathrm{LiNbO}_{3}$-type $\mathrm{FeTiO}_{3}$ phase was first reported in the Ries crater (Dubrovinsky et al. 2009). The phase was also found in the Suizhou L6 ordinary chondrite and named wangdaodeite after D. Wang (Xie et al. 2020). Schreyerite-type $\left(\mathrm{Ti}^{4+} \mathrm{Fe}^{2+}\right) \mathrm{Ti}_{3}{ }^{4+} \mathrm{O}_{9}$ phase was found in the meltpocket of the eucrite NWA 8003 and named vestaite after the name of its parental asteroid Vesta (Pang et al. 2018). $\mathrm{Sr}_{2} \mathrm{Tl}_{2} \mathrm{O}_{5}$-type $\mathrm{Fe}_{2}^{2+}\left(\mathrm{Fe}^{2+} \mathrm{Ti}^{4+}\right) \mathrm{O}_{5}$ phase and $\mathrm{GdFeO}_{3}$-type $\mathrm{FeTiO}_{3}$ have been recently reported from the Martian meteorite Shergotty and named feiite after Y. Fei and liuite after L.-G. Liu, respectively (Ma et al. 2021b). In the same meteorite, $\mathrm{CaTi}_{2} \mathrm{O}_{4}$-type $\left(\mathrm{Fe}^{2+}\right)\left(\mathrm{Fe}^{2+} \mathrm{Ti}^{4+}\right) \mathrm{O}_{4}$ ( simply $\mathrm{Fe}_{2} \mathrm{TiO}_{4}$ ) with a post-spinel structure was also discovered (Ma et al. 2021a) and was named tschaunerite after O. Tschauner. $\mathrm{CaGa}_{2} \mathrm{O}_{4}$-type $\mathrm{CaAl}_{2} \mathrm{O}_{4}$ was discovered in a $\mathrm{Ca}-\mathrm{Al}$-rich inclusion (CAI) of the NWA $470 \mathrm{CH} 3$ carbonaceous chondrite and named domitryivanovite after D. A. Ivanov (Mikouchi et al. 2009). The mineral was also reported in an unusual $\mathrm{Ca}-\mathrm{Al}-\mathrm{Fe}$ rich inclusion in the Vigarano CV3 carbonaceous chondrite (Maruyama and Tomioka 2011). Previous high-pressure experiments suggest that domitryivanovite is stable above $\sim 2 \mathrm{GPa}$ (Ito et al. 1980).

\subsubsection{High-pressure polymorphs of other high-pressure $(\mathrm{Mg}, \mathrm{Fe})$-silicates}

Interestingly, a new phase found as a unique grain in a shock-melt vein of the Suizhou L6 ordinary chondrite has the composition of $(\mathrm{Mg}, \mathrm{Fe})_{5} \mathrm{Si}_{2} \mathrm{O}_{9}$ and was named

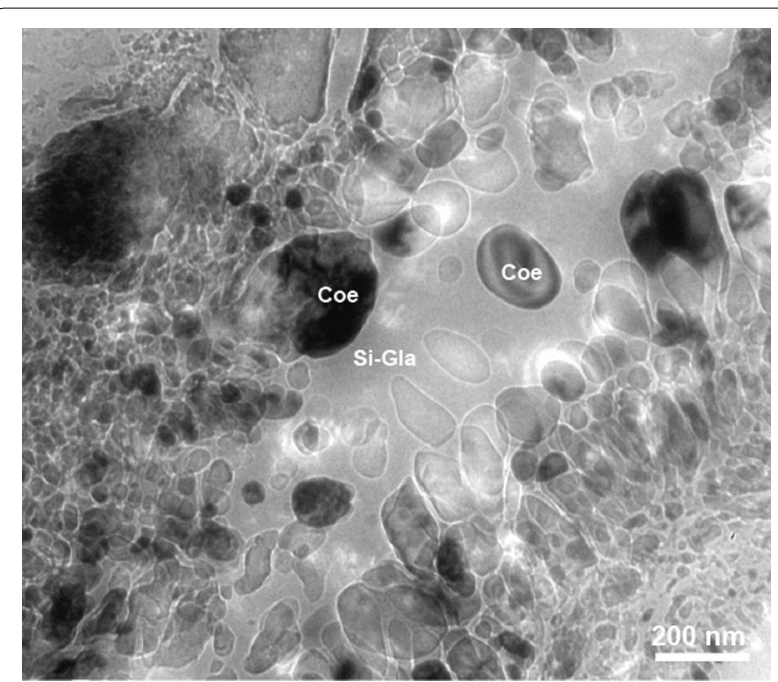

Fig. 10 BF-TEM image of coesite in the eucrite Béréba. Spherical coesite crystals have formed in cristobalite or tridymite grains in contact with the shock-melt veins of Béréba. A part of the original silica has become amorphous. Coe: coesite, Si-Gla: silica-glass

elgoresyite after A. El Goresy (Bindi et al. 2021). The crystal structure of this new iron-magnesium silicate, never obtained in laboratory experiments so far, is the same as the iron oxide $\mathrm{Fe}_{7} \mathrm{O}_{9}$, strongly suggesting that silicates also form the $((\mathrm{Mg}, \mathrm{Fe}) \mathrm{O})_{\mathrm{m}+\mathrm{n}}\left(\mathrm{SiO}_{2}\right)_{\mathrm{n}}$ series that are isostructural to iron oxides via $\left(\mathrm{Mg}^{2+}, \mathrm{Fe}^{2+}\right)+\mathrm{Si}^{4+}=2 \mathrm{Fe}^{3+}$ substitution. The newly found iron-magnesium silicate is a potential constituent mineral in rocky planets with relatively high $\mathrm{MgO}+\mathrm{FeO}$ content.

\subsubsection{High-pressure polymorph of phosphide}

$\mathrm{Co}_{2} \mathrm{Si}$-type $(\mathrm{Fe}, \mathrm{Ni})_{2} \mathrm{P}$ was discovered in the Onello iron meteorite and named allabogdanite after A. N. Bogdanova (Britvin et al. 2002). The mineral was regarded to be a high-pressure polymorph of barringerite that is stable above $6 \mathrm{GPa}$ and $900{ }^{\circ} \mathrm{C}$ based on previous high-pressure experiments (Dera et al. 2008) and natural occurrences in several other iron meteorites (Britvin et al. 2019). However, further detailed experimental and theoretical studies clarified that the mineral is also stable at ambient pressure below $500{ }^{\circ} \mathrm{C}$ (Litasov et al. 2020). Hence, the results suggest a possibility that the formation of allabogranite in iron meteorites does not require shock metamorphism.

\subsubsection{High-pressure polymorphs of carbon}

The first natural occurrence of diamond in shocked materials was reported, as in the Novo-Urei ureilite, in the late nineteenth century (Kunz 1888) and have currently been found in more than 10 ureilites (e.g., Goodrich et al. 


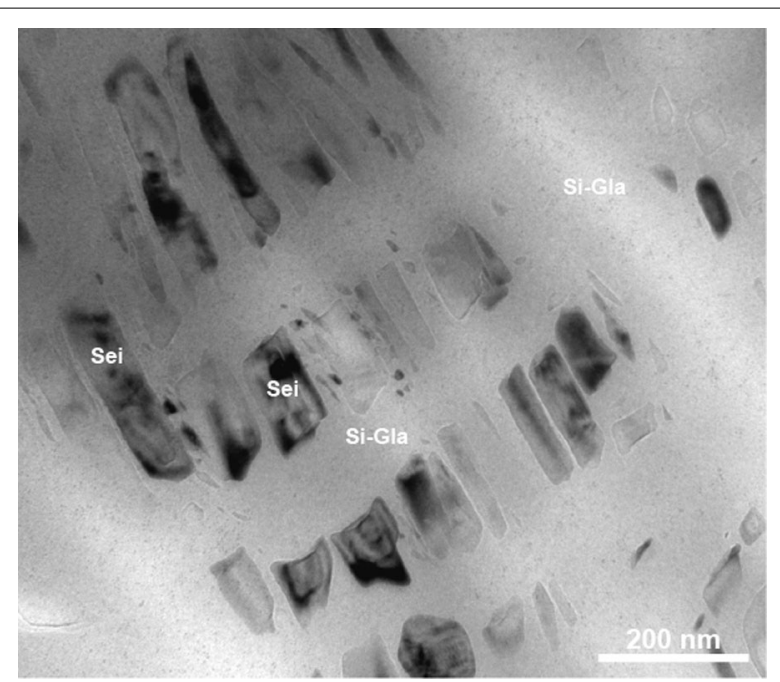

Fig. 11 BF-TEM image of seifertite in the basaltic lunar meteorite Northwest Africa (NWA) 4734. Lath-like seifertite crystals have formed in cristobalite grains in contact with the shock-melt veins of NWA 4734. Most parts of the original cristobalite grains have become amorphous. Sei: seifertite, Si-Gla: silica-glass

2004; Miyahara et al. 2015; Nestola et al. 2020; Barbaro et al. 2021). Experimental works on the synthesis of diamond for industrial purposes succeeded by static compression of graphite over 3 GPa by Bundy et al. (1955) and shock-synthesized at $30 \mathrm{GPa}$ by DeCarli and Jamieson (1961). Diamonds in ureilites are also expected to be formed under transient high-pressure condition shock metamorphism (e.g., Berkley et al. 1976; Nakamuta and Aoki 2000; Nakamuta and Toh 2013; Nestola et al. 2020). On the other hand, some diamonds might form under static high-pressure conditions in the deep interior of an ureilite parent body (Urey 1956; Miyahara et al. 2015; Nabiei et al. 2018) or at low pressure through chemical vapor deposition (Fukunaga et al. 1987).

\subsection{Natural quasicrystals}

One of the most remarkable findings of exotic extraterrestrial materials has been the discovery of natural quasicrystals (QCs) (Bindi et al. 2009, 2012). They have been detected as rare materials in the Khatyrka meteorite, a peculiar CV3 carbonaceous chondrite (MacPherson et al. 2013) containing $\mathrm{Cu}, \mathrm{Al}$-metallic compounds. QCs, short for quasiperiodic crystals, are solids that are able to violate the conventional rules of crystallography because their structure is quasiperiodic rather than periodic (Bindi et al. 2020b). The first quasicrystalline phase found in nature, icosahedrite $\mathrm{Al}_{63} \mathrm{Cu}_{24} \mathrm{Fe}_{13}$ (Fig. 12) (Bindi et al. 2009, 2011), displayed a five-fold symmetry in two dimensions and icosahedral symmetry in three dimensions. Then, a second QC, decagonite $\mathrm{Al}_{71} \mathrm{Ni}_{24} \mathrm{Fe}_{5}$ (Bindi et al. 2015a, 2015b), was found in the same meteorite and it was the first mineral to exhibit crystallographically forbidden decagonal symmetry. Both icosahedrite and decagonite, however, showed compositions matching those of synthetic quasicrystalline phases found earlier (Tsai et al. $1987,1989)$ in the laboratory at standard pressure.

The origin of these unusual metallic alloys is enigmatic as they contain metallic aluminum that forms under highly reducing conditions not normally found in nature. Furthermore, the puzzling combination of metallic aluminum, a refractory lithophile element, and copper, a moderately volatile siderophile or chalcophile element, makes these alloys even more mysterious. When first reported, a plausible explanation was that the samples were byproducts of some laboratory or industrial process. Previous and successive studies, however, provided compelling evidence that the quasicrystals are natural and from a common meteoritic source: (i) ${ }^{14} \mathrm{C}$-dating of materials from undisturbed clay layers where some of the samples were collected yielded 6.7-8.0 ka BP, (ii) the $\mathrm{Cu}-$ $\mathrm{Al}$ metallic alloys were found to be intimately intermixed with oxides/silicates with nonterrestrial oxygen isotope composition (Hollister et al. 2014; Lin et al. 2017), (iii) clear evidence was found of high-pressure-induced phase transitions requiring transient conditions consistent with an asteroidal collision event, at least $5 \mathrm{GPa}$ and $1200{ }^{\circ} \mathrm{C}$, sufficient to melt and rapidly quench the $\mathrm{Al}-\mathrm{Cu}$ bearing alloys (Asimow et al. 2016), (iv) noble gas measurements confirmed that the shock event reached pressure above $5 \mathrm{GPa}$ and occurred at least hundreds of million years ago (Meier et al. 2018), and (v) robust petrographic and chemical evidence established that some metallic alloy grains (including QCs) found in the samples predated the shocks. Moreover, the recent discovery of a COtype chondritic spherule from the Nubian desert, Sudan (Suttle et al. 2019), containing the same assemblage of aluminum, iron, and copper and with a morphology remarkably similar to Khatyrka provided further support and independent evidence that these samples were formed in outer space.

By means of laser ablation inductively coupled plasma mass spectrometry measurements of the trace element contents of the two naturally occurring quasicrystalline minerals, $\mathrm{Al}_{63} \mathrm{Cu}_{24} \mathrm{Fe}_{13}$ icosahedrite and $\mathrm{Al}_{71} \mathrm{Ni}_{24} \mathrm{Fe}_{5}$ decagonite, Tommasini et al. (2021) hypothesized a three-stage model for the formation of the quasicrystals and their inclusions: a high-temperature condensation stage and a low-temperature vapor-fractionation stage to make nanoparticles, followed by a third stage that leads to the formation of quasicrystals incorporating the two different types of nanoparticles and their incorporation into the $\mathrm{CV}$ chondrite parent body of the Khatyrka meteorite. 
In a recent speculative essay, Bindi et al. (2020a) reported that although the only known examples of natural quasicrystals are from the Khatyrka meteorite, this does not necessarily mean that quasicrystals must be extremely rare in the universe. The authors present several reasons why quasicrystals may prove to be among the most ubiquitous minerals found in the universe.

\subsection{Significance of high-pressure minerals from meteorites} Ringwoodite can be identified easily by an optical microscope because it shows purple/blue color in transmitted light. Hence, in the classic shock classification criterion (S1-S6), the identification of ringwoodite in ordinary chondrites became a criterion for very strongly shocked (S6) (Stöffler et al. 1991). Many kinds of high-pressure minerals were found from ordinary chondrites after the shock classification criterion was proposed. The criterion was revised, Stöffler et al. (2018) defining that not only ringwoodite but also wadsleyite, ahrensite, majorite, akimotoite, bridgmanite, and lingunite may be present in ordinary chondrite that satisfies shock stages S5-S6.

High-pressure melting experiments of the Allende CV3 carbonaceous chondrite and peridotite were conducted, and their phase equilibrium diagrams were obtained using their run products (Zhang and Herzberg 1994; Agee et al. 1995). There are similarities in the species, assemblages, chemical compositions, and grain sizes of high-pressure minerals between the recovered samples and constituents in shock-melt veins. Based on the similarities, Chen et al. (1996) estimated the shock pressure and temperature recorded in a shock-melt vein using the phase equilibria diagrams. This scheme was applied to several ordinary chondrites, eucrites, Martian, and lunar meteorites to estimate the shock pressure and temperature (e.g., Xie et al. 2003, 2006; Ohtani et al. 2004; El Goresy et al. 2013; Pang et al. 2016; Zhang et al. 2021).

The major disruption that occurred on the early parent body of ordinary chondrites was deduced by the systematic investigations of high-pressure minerals (Miyahara et al. 2020). Most ordinary chondrites have experienced thermal metamorphism after accumulation into the early parent body. Based on the maximum metamorphic temperature and cooling rate recorded in each ordinary chondrite, the early parent body of ordinary chondrites had an onion shell structure before its major disruption (e.g., Trieloff et al. 2003). Assuming the onion shell model, shock pressure should be the highest at the surface (least thermally metamorphosed one: petrographic type 3) of the parent body. However, unexpectedly, the shock pressure estimated by high-pressure minerals increases with increasing petrographic type from 3 to 6 (petrographic type 6 is the highest thermally metamorphosed one corresponding to the deepest interior of the parent body) (Miyahara et al. 2020). The results suggest that the apparent lower shock pressure on the surface would be explained by spallation at the opposite side of the parent body to the impact point.

Recent studies point out that shock metamorphism recorded in shocked meteorites is not simple. Some ordinary chondrites seem to record a dual impact because (i) a shock-melt vein is penetrated by another shock-melt vein (Hu and Sharp 2016) and (ii) a high-pressure polymorph includes another high-pressure polymorph indicating different shock pressures (Miyahara et al. 2011a). The dual impact (or dual heating event) record is also deduced from radioisotope ages in some shocked meteorites (e.g., Treiman et al. 2007).

The formation of a high-pressure mineral and resetting of a radioisotope's age depend on the thermal history. However, the thermal history recorded in a shock-melt vein or melt-pocket is also complex. Pressure decreases drastically (several microseconds' order) but temperature decreases gradually (several seconds' order) during an adiabatic decompression stage, resulting in low-pressure and high-temperature conditions. If the low-pressure and high-temperature conditions are prolonged, the back transformation of a high-pressure mineral occurs, which underestimates the shock pressure (Kimura et al. 2004; $\mathrm{Hu}$ and Sharp 2017; Miyahara et al. 2019). However, a back-transformation mechanism of a high-pressure mineral and its kinetics have not been deeply investigated except for a few works (Ming et al. 1991; Fukimoto et al. 2020; Miyahara et al. 2021). We must work on these issues to trace a pressure-temperature-time path recorded in a shock-melt vein or melt-pocket as future work.

Phase transformation is kinetically controlled. Ohtani et al. (2004) suggested estimating the magnitude of an impact event recorded in an ordinary chondrite using the grain-growth kinetics of ringwoodite. The grain sizes of ringwoodite crystals in shocked ordinary chondrites are similar to each other (across $<1-2 \mu \mathrm{m}$ ) (Ohtani et al. 2004; Miyahara et al. 2010; Kato et al. 2017). Hence, the estimated duration of shock pressure is almost the same

(See figure on next page.)

Fig. 12 BSE images of icosahedrite in the Khatyrka CV3 carbonaceous chondrite. a Grain 126A of Khatyrka CV3 carbonaceous chondrite. A red dashed box indicates the region to be enlarged in $\mathbf{b}$. $\mathbf{b}$ The area where there is the metal assemblage containing the icosahedral phase (icosahedrite). c The enlarged image of the region indicated by a red dashed box in the panel $\mathbf{b}$. $\mathbf{d}$ Electron backscatter diffraction pattern of the icosahedral phase obtained from the region marked with a cross in the inset. The pattern matches that predicted for a face-centered icosahedral quasicrystal 

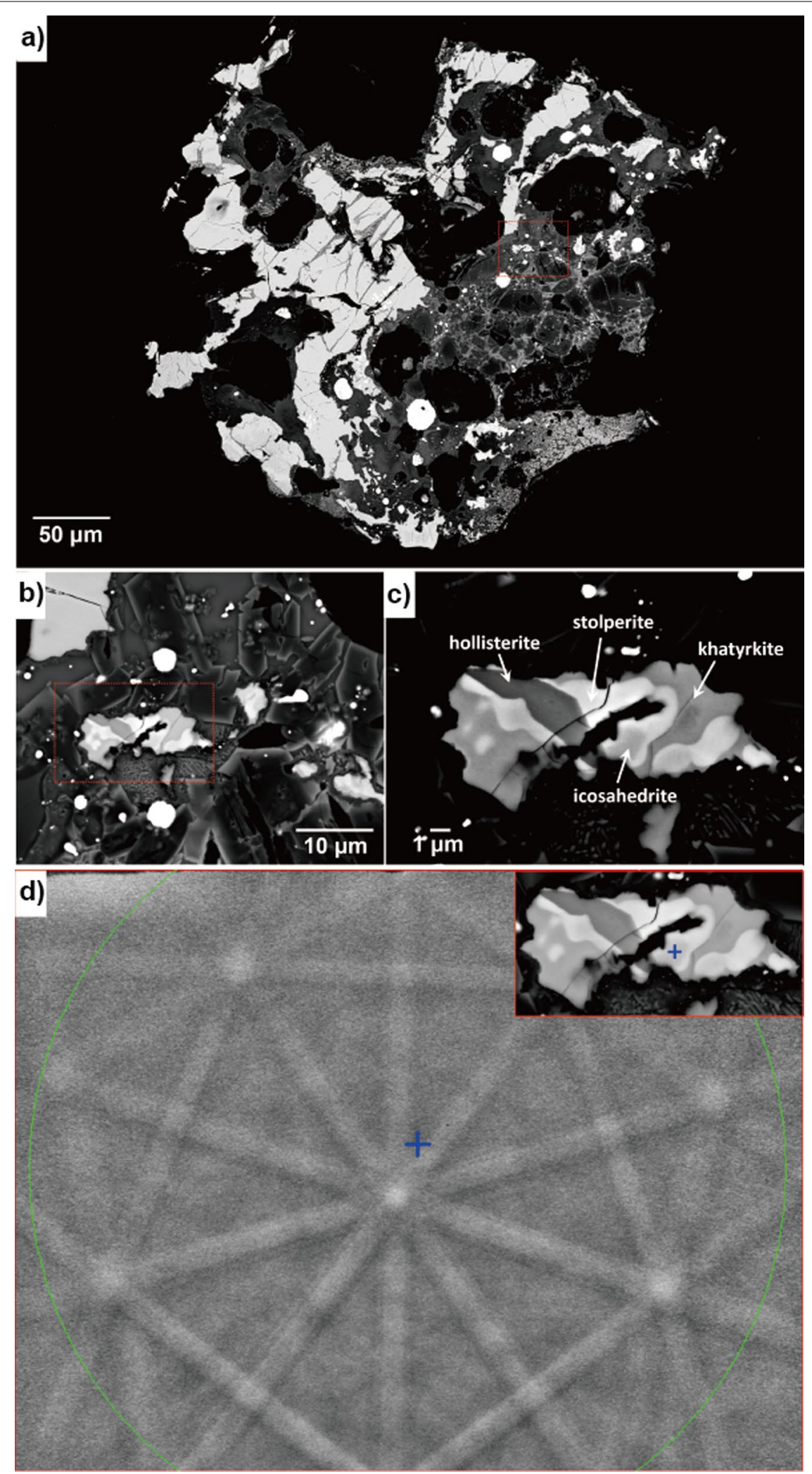

Fig. 12 (See legend on previous page.) 
(< several seconds) (Ohtani et al. 2004; Xie et al. 2006; Sharp et al. 2015). Also, the phase transition rates of plagioclase and silica are applied to estimate the duration of shock pressure $(<\sim 5 \mathrm{~s})$ in some ordinary chondrites and lunar meteorites (Kubo et al. 2010; Miyahara et al. 2013a, 2017; Ozawa et al. 2014). On the other hand, recent timeresolved femtosecond diffractometry using an X-ray freeelectron laser revealed that ringwoodite can form from laser shock compressed olivine through ultrafast lattice shearing in nanoseconds (Okuchi et al. 2021).

\section{High-pressure minerals in impact craters}

\subsection{High-pressure polymorphs of carbon}

In terrestrial impact structures, diamond was found in the Barringer (Ksanda and Henderson 1939), Ries (Hough et al. 1995), Zapadnaya (Gurov et al. 1995), and Popigai (Koeberl et al. 1997) craters. A previous highpressure experiment succeeded in synthesizing nanopolycrystalline diamond (NPD) with grain sizes less than $100 \mathrm{~nm}$ by direct conversion from pure polycrystalline graphite at $12-25 \mathrm{GPa}$ and $2300-2500{ }^{\circ} \mathrm{C}$ (Irifune et al. 2003). The NPD was brought to material scientists' attention because it has a larger stiffness than a single-crystal diamond. Its natural analog was also discovered from the Popigai impact crater (Ohfuji et al. 2015).

A modified diamond structure with a hexagonal cell was synthesized by a high-pressure experiment (Bundy and Kasper 1967). The natural hexagonal diamond was first found in the Barringer crater and was named lonsdaleite after K. Lonsdale (Frondel and Marvin 1967). It is a very enigmatic mineral. It was also discussed that it should not exist as a discrete mineral because it could correspond to a faulted and twinned cubic diamond (Németh et al. 2014). In the Popigai crater, both diamond and lonsdaleite were found in impact melt rock and breccia. These high-pressure phases of carbon have been formed from graphite in the target gneissic rocks by lattice-shear (martensitic) transformation mechanisms of the graphite structure by shock metamorphism (Koeberl et al. 1997; Nakamuta and Toh 2013). The formation of diamond and lonsdaleite was estimated at 35-60 GPa based on shock effects on the host-rock minerals.

A novel carbon crystal was reported in the Ries crater. The crystal shows a diffraction pattern different from those of preexisting crystalline carbon polymorphs (graphite, diamond, or lonsdaleite) and named chaoite, as mentioned previously (El Goresy and Donnay 1968). A similar allotropic form of carbon was synthesized during the sublimation of pyrolytic graphite (Whittaker and Kintner 1969). The mineral is thought to have a crystal structure comprising chains with alternating single and triple bonds $(-\mathrm{C} \equiv \mathrm{C}-$ ), which is called the carbyne structure. Five variations of carbynes were also found from the Allende and Murchison carbonaceous chondrites (Whittaker et al. 1980). The finding was once questioned and claimed as misidentified phases by powder XRD as a mixture of quartz and Fe-smectite (Smith and Buseck 1982). However, subsequent experimental studies ensure the existence of carbynes (e.g., Chalifoux and Tykwinski 2010; Pan et al. 2015). First-principles' calculations clarified that carbyne is about twice as stiff as the stiffest known materials under tension (Liu et al. 2013); therefore, chaoite is also a potentially important mineral for material science.

Another novel allotropic carbon was discovered in a shocked gneiss from the Popigai impact crater (El Goresy et al. 2003). Carbon platelets, embedded in quartz and cristobalite, consist of graphite and lonsdaleite and an unknown carbon phase. The unknown phase has considerably high polishing hardness overcoming diamond powder. Synchrotron XRD clarified that the phase has a cubic cell with the space group $P m-3 m$, although its density and the detailed crystal structure have not yet been obtained. Its origin and formation conditions are also unknown because of a lack of experimental and theoretical studies.

Finally, Németh and Garvie (2020) have recently reported the discovery of cage-like nanostructured carbonaceous materials, including carbon nano-onions and bucky-diamonds, formed through extraterrestrial impacts in the Gujba $\mathrm{CB}_{\mathrm{a}}$ carbonaceous chondrite.

\subsection{High-pressure polymorphs of silica}

Dense $\mathrm{SiO}_{2}$ crystals are the first synthesized minerals among silicates and oxides related to the Earth and planetary materials. Coesite and stishovite were first synthesized by static compression by Coes (1953) and Stishov and Popova (1961), respectively, and stishovite was also shock-synthesized by DeCarli and Milton (1965). Phase equilibria studies based on static highpressure experiments clarified that coesite and stishovite are stable above $\sim 2 \mathrm{GPa}$ and $\sim 8 \mathrm{GPa}$, respectively. Stishovite was shock-synthesized at pressure over 12 $\mathrm{GPa}$, while there is no convincing report that coesite can be formed by shock recovery experiments. Smaller shock pressure duration $\left(10^{-6} \mathrm{~s}\right)$ in laboratory shock experiments than that in terrestrial impact cratering $\left(>10^{-3}\right.$ s) (Kieffer 1971) and sluggish kinetics in the quartz to coesite transformation would cause difficulty in the artificial production of the mineral (e.g., Nagai et al. 1997; Perrillat et al. 2003).

The first finding of natural dense silica was performed in the early 1960s. E. C. T. Chao and his colleagues applied hydrofluoric acid leaching to a large amount of the Coconino sandstone of the Barringer crater, which 
was produced by the impact of the Canyon Diablo iron meteorite $\sim 49,000$ years ago. Coesite and stishovite, the high-pressure polymorphs of $\mathrm{SiO}_{2}$, were identified in the residues by powder XRD (Chao et al. 1960, 1962). In particular, coesite is one of robust evidence for impact origin and found in over 20 impact craters. Stishovite has been found in three more impact craters, namely Popigai (Vishnevsky et al. 1975), Ries (Stöffler 1971; Stähle et al. 2007), and Vredefort (Martini 1978, 1991; Spray and Boonsue 2018), in addition to the Barringer crater.

\subsection{High-pressure polymorphs of $\mathrm{TiO}_{2}$}

Rutile transforms into scrutinyite $\left(\alpha-\mathrm{PbO}_{2}, \mathrm{TiO}_{2}-\mathrm{II}\right)$, baddeleyite $\left(\mathrm{ZrO}_{2}\right)$, orthorhombic-I, and cotunnite structures with increasing pressure (Nishio-Hamane et al. 2010). Scrutinyite-type $\mathrm{TiO}_{2}$ with an orthorhombic cell was first synthesized by a static compression experiment (Bendeliany et al. 1966). In nature, almost pure scrutinyite-type $\mathrm{TiO}_{2}$ was first discovered in shocked garnet gneisses from the Ries crater (El Goresy et al. 2001). The phase was also found from suevite in a drilling core of granitic basement rock from the Chicxulub crater (Kring et al. 2020), which was estimated to have been shocked at $\sim 20 \mathrm{GPa}$ in the Cretaceous-Paleogene boundary (Timms et al. 2019). The $\mathrm{TiO}_{2}$-rich scrutinyitephase had been known as mineral srilankite $\left[(\mathrm{Ti}, \mathrm{Zr}) \mathrm{O}_{2}\right]$, where $\mathrm{Ti}$ and $\mathrm{Zr}$ ions are disordered at the cation sites. The Ries crater also yielded almost pure $\mathrm{TiO}_{2}$ with the scrutinyite-like structure that was named riesite after the name of the location (Tschauner et al. 2020b). Riesite occurs in shock-melt veins within xenoliths of bedrock in suevite. Srilankite has one cation site for $\mathrm{Ti}$ and $\mathrm{Zr}$ ions and one oxygen site, while there are two cation and oxygen sites each in the riesite structure, causing the monoclinic distortion. Riesite has not been synthesized, but its higher density $\left(4.37 \mathrm{~g} / \mathrm{cm}^{3}\right)$ than rutile $\left(4.25 \mathrm{~g} / \mathrm{cm}^{3}\right)$ suggests riesite is a high-pressure mineral. Thus, riesite has formed through the back transformation from the baddeleyite phase upon pressure release.

Baddeleyite-type $\mathrm{TiO}_{2}$, which has 7-coordinated Ti ions, was first observed at $20 \mathrm{GPa}, 770{ }^{\circ} \mathrm{C}$ by in situ XRD using a Kawai-type high-pressure apparatus (Sato et al. 1991) but could not be recovered at ambient condition. In contrast, in nature, baddeleyite-type $\mathrm{TiO}_{2}$ was first found in the suevite breccia from the Ries crater and named akaogiite after M. Akaogi (El Goresy et al. 2001, 2010).

\subsection{High-pressure polymorphs of $\mathrm{MgFe}_{2} \mathrm{O}_{4}$}

A high-pressure phase of magnesioferrite $\left(\mathrm{MgFe}_{2} \mathrm{O}_{4}\right)$ was discovered in a drill core of shocked diamond-bearing gneiss from the Xiuyan crater (Chen et al. 2019). Powder
XRD and TEM clarified that the mineral has the harmunite $\left(\mathrm{CaFe}_{2} \mathrm{O}_{4}\right)$ structure as same as chenmingite $\left(\mathrm{FeCr}_{2} \mathrm{O}_{4}\right)$ discovered in the Suizhou L6 ordinary chondrite (Chen et al. 2003b) and the shergottite Tissint (Chen et al. 2019). The mineral was named maohokite after H.-K. Mao (Chen et al. 2019). Maohokite coexists with magnesioferrite embedded in calcite and is thought to be a decomposed product of ankerite. The high-pressure phase equilibria of $\mathrm{MgFe}_{2} \mathrm{O}_{4}$ have not been established by experimental studies. However, based on pressure and temperature conditions for the post-spinel transformation (e.g., Andrault et al. 2001), maohokite is thought to have formed at $25-45 \mathrm{GPa}$ and $800-900{ }^{\circ} \mathrm{C}$ (Chen et al. 2019).

\subsection{High-pressure polymorphs of $\mathrm{ZrSiO}_{4}$}

The high-pressure phase of zircon is an important key mineral to understanding the shock metamorphism in impact craters because of its robustness against weathering. The scheelite $\left(\mathrm{CaWO}_{4}\right)$-type $\mathrm{ZrSiO}_{4}$ was discovered in the upper Eocene impact ejecta layer in marine sediments by powder XRD and named reidite after A. F. Reid who first synthesized this phase (Glass and Liu 2001; Glass et al. 2002). Subsequently, reidite was found in five impact craters: Chesapeake Bay (Malone et al. 2010), Xiuyan (Chen et al. 2013), Rock Elm (Cavosie et al. 2015), Ries (Erickson et al. 2017), and Woodleigh (Cox et al. 2018) craters. Shock recovery experiments of zircon indicate that the transition to reidite is above $\sim 30 \mathrm{GPa}$ (Kusaba et al. 1985), while static high-pressure experiments demonstrated that the stability field of the phase is in the pressure range of $\sim 8-25$ GPa (Ono et al. 2004; Tange and Takahashi 2004). The discrepancy between two shock pressure estimations would be caused by different high-pressure timescale and/or differential stress between the static and dynamic high-pressure experiments.

\subsection{Significance of high-pressure minerals from impact crater rocks}

High-pressure minerals do not occur as commonly in terrestrial impact craters when compared with those in shocked meteorites. One of the possible reasons is the different cooling histories after shock pressure release between the surface materials of asteroids and the Earth's crust. Shocked surface rocks in the parent bodies of meteorites are excavated and released to space, resulting in rapid cooling. In terrestrial impact craters, part of the surface and near-surface materials are ejected and also rapidly cooled to preserve highpressure minerals, which are mostly inclusions in lithic impact breccia (suevite). Nevertheless, the materials in larger burial depths of the craters such as those in 
thick sediments and basement rocks should experience longer residual shock heating because the temperature decreased mainly by thermal conduction within the rocks. In such a case, high-pressure minerals would have been back-transformed to low-pressure minerals even if they were once formed during shock metamorphism. Another reason for the weak preservation of high-pressure minerals is aqueous alterations after the crater formation. Abundant shock-induced fractures play a role in fluid pathways, and fine-grain size and glassy materials containing high-pressure minerals are susceptible to alterations by weathering and impactinduced hydrothermal activities (Grieve et al. 1996; Kring et al. 2020).

Nevertheless, technical developments on microanalyses and constant efforts by impact petrologists enabled the findings of many high-pressure minerals from impact craters. Since the discovery of coesite in the Barringer crater, over 10 new high-pressure minerals have been found from terrestrial impact craters (Table 1). These dense minerals are direct and robust evidence for the impact origin (but not a volcanic origin) of the craters. Thus far, shock microstructures of quartz and, in particular, crystallographic orientations of planar deformation features are commonly used to evaluate shock pressures in the pressure range of $\sim 10-35 \mathrm{GPa}$ of sedimentary and granitic rocks in impact craters (Langenhorst 2002; Stöffler et al. 2018). Also, phase transformations of quartz such as formations of diaplectic (dense) glass, lechatelierite (normal glass), coesite, and stishovite further provide pressure constraints in a wider pressure range. A recently found superstructure of quartz from the basement rock of the Chicxulub crater (Tani et al. 2018) is another possible shock pressure indicator. The previously described high-pressure phases of carbon, oxides, and silicates would also contribute to elucidate spatial shock pressure distribution in impact structures considering the results of static and dynamic high-pressure experiments.

The attenuation of shock pressure in impact cratering is expressed by the following equation, $P=P_{0}(R /$ $L p)^{-b}$, where pressure $P$ at the distance $R$ from the isobaric core is a function of initial peak pressure $P_{0}, R$, the radius of impactor $L p$, and attenuation coefficient of shock wave $b$ (Mizutani et al. 1990). When we can obtain a shock pressure gradient based on pressures of different locations within an impact crater, the size of the impactor can be constrained. For this purpose, the occurrences of high-pressure minerals can be useful anchor points of shock pressures.

Shock pressure distribution during impact cratering is one of the most fundamental parameters to understand shock temperature distribution, rock deformation, and impactor's size and velocities. The information is closely related to impact-induced phenomena such as the size and morphologies of the impact craters (Morgan et al. 2016; Riller et al. 2018), post-impact hydrothermal activities (Kring et al. 2020), atmospheric conditional changes (Artemieva et al. 2017), and biological mass extinctions (Lowery et al. 2018). Therefore, future research of high-pressure minerals will play important roles to elucidate how the impacts of extraterrestrial materials affect Earth's environments.

\section{Summary}

Pioneer works in the 1960 s by R. A. Binns, E. C. T. Chao, A. El Goresy, and their colleagues clarified the presence of high-pressure minerals in shocked meteorites and rocks around terrestrial craters. After their discoveries, mineralogists and planetary scientists have continued to find high-pressure minerals from natural shocked materials. The identification of new high-pressure minerals has increased drastically in the twenty-first century because of the introduction of nanoanalysis technologies. The search for high-pressure minerals in shocked materials was initiated by finding the analog materials of the deep Earth's interior. This initial purpose is almost achieved at present. However, the crystal structures and formation mechanisms of high-pressure minerals in naturally shocked materials are more complicated than those expected based on experiments and theoretical simulations. As the next step, we aim for better quantification of P-T histories of the shocked metamorphism based on the high-pressure and high-temperature transformation kinetics and of impact histories in the solar system by combining shock petrography and radioisotope ages.

\section{Acknowledgements \\ We dedicate this paper to Prof. Ahmed El Goresy (1934-2019) who devoted his life to science. In 2020, a new high-pressure mineral was named elgoresyite after Ahmed El Goresy in honor of his contributions. We appreciate the helpful comments and suggestions by reviewers Profs. M. Akaogi and S. Xie as well as an associate editor Prof. M. Kimura. We also thank Profs. E. Ohtani, A. Yamagu- chi, T. Kubo, Drs. S. Ozawa, and Y. Kodama for their constructive comments and technical assistance.}

\section{Authors' contributions}

$\mathrm{MM}, \mathrm{NT}$, and LB conceived this review and collected and arranged the previous studies. MM, NT, and LB wrote the manuscript. All authors read and approved the final manuscript.

\section{Funding}

This study was supported by Grants-in-Aid for Scientific Research No. $18 \mathrm{H} 01269$ and $20 \mathrm{H} 01965$ by MEXT to M. M and N. T., respectively. This study was also supported by NIPR, Japan, through General Collaboration Project No. 26-31, No. 31-25, and Project Research KP-307. This work was in part supported by Hiroshima Institute of Plate Convergence Region Research (HiPeR) (the MEXT program for promoting the enhancement of research universities, Japan). 


\section{Availability of data and materials}

Representative occurrences, transformation mechanisms, and Raman spectra of high-pressure polymorphs are in Tomioka and Miyahara (2017). The inventory of high-pressure polymorphs in shocked meteorites is included in Tomioka and Miyahara (2017) and Miyahara et al. (2020). The latest information about high-pressure minerals is available at https://sites.google.com/site/ highpmineral.

\section{Declarations}

\section{Competing interests}

The authors declare that we have no competing interests.

\section{Author details}

${ }^{1}$ Graduate School of Advanced Science and Engineering, Hiroshima University, Higashihiroshima 739-8526, Japan. ${ }^{2}$ Kochi Institute for Core Sample Research, Japan Agency for Marine-Earth Science and Technology (JAMSTEC), Nankoku, Kochi 783-8502, Japan. ${ }^{3}$ Dipartimento Di Scienze Della Terra, Università Degli Studi Di Firenze, Via G. La Pira 4, 50121 Florence, Italy.

Received: 17 May 2021 Accepted: 29 September 2021

Published online: 18 October 2021

\section{References}

Agarwal A, Reznik B, Kontny A, Heissler S, Schilling F (2016) Lingunite-a highpressure plagioclase polymorph at mineral interfaces in doleritic rock of the Lockne impact structure (Sweden). Sci Rep 6:25991

Agee CB, Li J, Shannon MC, Circone S (1995) Pressure-temperature phase diagram for the Allende meteorite. J Geophys Res: Solid Earth 100:17725-17740

Andrault D, Bolfan-Casanova N, Guignot N (2001) Equation of state of lower mantle (Al, Fe)-MgSiO 3 perovskite. Earth Planet Sci Lett 193:501-508

Angel RJ, Finger LW, Hazen RM, Kanzaki M, Weidner DJ, Liebermann RC, Veblen $\mathrm{DR}$ (1989) Structure and twinning of single-crystal $\mathrm{MgSiO}_{3}$ garnet synthesized at $17 \mathrm{GPa}$ and $1800^{\circ} \mathrm{C}$. Am Min 74:509-512

Angel RJ, Chopelas A, Ross NL (1992) Stability of high-density clinoenstatite at upper-mantle pressures. Nature 358:322-324

Artemieva N, Morgan J, Party ES (2017) Quantifying the release of climateactive gases by large meteorite impacts with a case study of Chicxulub. Geophys Res Lett 44:10180-10188

Asimow PD, Lin C, Bindi L, Ma C, Tschauner O, Hollister LS, Steinhardt PJ (2016) Shock synthesis of quasicrystals with implications for their origin in asteroid collisions. Proc Natl Acad Sci USA 113:7077-7081

Bandfield JL (2007) High-resolution subsurface water-ice distributions on Mars. Nature 447:64-67

Barbaro A, Chiara Domeneghetti M, Litasov KD, Ferrière L, Pittarello L, Christ O, Lorenzon S, Alvaro M, Nestola F (2021) Origin of micrometer-sized impact diamonds in ureilites by catalytic growth involving $\mathrm{Fe}-\mathrm{Ni}$ silicide: the example of Kenna meteorite. Geochim Cosmochim Acta. https://doi.org/10.1016/j.gca.2021.06.022

Baziotis I, Asimow PD, Hu J, Ferriere L, Ma C, Cernok A, Anand M, Topa D (2018) High pressure minerals in the Chateau-Renard (L6) ordinary chondrite: implications for collisions on its parent body. Sci Rep 8:9851

Beck P, Gillet P, Gautron L, Daniel I, El Goresy A (2004) A new natural high-pressure $(\mathrm{Na}, \mathrm{Ca})$-hexaluminosilicate $\left[\left(\mathrm{Ca}_{x} \mathrm{Na}_{1-x}\right) \mathrm{Al}_{3+x} \mathrm{Si}_{3-x} \mathrm{O}_{11}\right]$ in shocked Martian meteorites. Earth Planet Sci Lett 219:1-12

Beck P, Barrat JA, Gillet P, Wadhwa M, Franchi IA, Greenwood RC, Bohn M, Cotten J, van de Moortèle B, Reynard B (2006) Petrography and geochemistry of the chassignite Northwest Africa 2737 (NWA 2737). Geochim Cosmochim Acta 70:2127-2139

Bendeliany N, St P, Vereschagin L (1966) A new modification of titanium dioxide stable at high pressure. Geokhimiya 5:499-502

Berkley JL, Brown HG, Keil K, Carter NL, Mercier JCC, Huss G (1976) The Kenna ureilite: an ultramafic rock with evidence for igneous, metamorphic, and shock origin. Geochim Cosmochim Acta 40:1429-1437

Bindi L, Steinhardt PJ, Yao N, Lu PJ (2009) Natural quasicrystals. Science 324:1306-1309
Bindi L, Steinhardt PJ, Yao N, Lu PJ (2011) Icosahedrite, $\mathrm{Al}_{63} \mathrm{Cu}_{24} \mathrm{Fe}_{13}$, the first natural quasicrystal. Am Min 96:928-931

Bindi L, Eiler JM, Guan Y, Hollister LS, MacPherson G, Steinhardt PJ, Yao N (2012) Evidence for the extraterrestrial origin of a natural quasicrystal. Proc Natl Acad Sci USA 109:1396-1401

Bindi L, Yao N, Lin C, Hollister LS, Andronicos CL, Distler WV, Eddy MP, Kostin A, Kryachko V, MacPherson GJ, Steinhardt WM, Yudovskaya M, Steinhardt PJ (2015a) Decagonite, $\mathrm{Al}_{71} \mathrm{Ni}_{24} \mathrm{Fe}_{5}$, a quasicrystal with decagonal symmetry from the Khatyrka CV3 carbonaceous chondrite. Am Min 100:2340-2343

Bindi L, Yao N, Lin C, Hollister LS, Andronicos CL, Distler WV, Eddy MP, Kostin A, Kryachko V, MacPherson GJ, Steinhardt WM, Yudovskaya M, Steinhardt PJ (2015b) Natural quasicrystal with decagonal symmetry. Sci Rep 5:9111

Bindi L, Chen M, Xie X (2017) Discovery of the Fe-analogue of akimotoite in the shocked Suizhou L6 chondrite. Sci Rep 7:42674

Bindi L, Griffin WL, Panero WR, Sirotkina E, Bobrov A, Irifune T (2018a) Synthesis of inverse ringwoodite sheds light on the subduction history of Tibetan ophiolites. Sci Rep 8:5457

Bindi L, Pham J, Steinhardt PJ (2018b) Previously unknown quasicrystal periodic approximant found in space. Sci Rep 8:16271

Bindi L, Brenker FE, Nestola F, Koch TE, Prior DJ, Lilly K, Krot AN, Bizzarro M, Xie X (2019) Discovery of asimowite, the Fe-analog of wadsleyite, in shock-melted silicate droplets of the Suizhou L6 and the Quebrada Chimborazo 001 CB3.0 chondrites. Am Min 104:775-778

Bindi L, Dmitrienko VE, Steinhardt PJ (2020a) Are quasicrystals really so rare in the Universe? Am Min 105:1121-1125

Bindi L, Nespolo M, Krivovichev SV, Chapuis G, Biagioni C (2020b) Producing highly complicated materials. Nature does it better. Rep Prog Phys 83:106501

Bindi L, Shim S-H, Sharp TG, Xie X (2020c) Evidence for the charge disproportionation of iron in extraterrestrial bridgmanite. Sci Adv 6:eaay7893

Bindi L, Welch MD, Bendeliani AA, Bobrov AV (2020d) Si-rich Mg-sursassite $\mathrm{Mg}_{4} \mathrm{Al}_{5} \mathrm{Si}_{7} \mathrm{O}_{23}(\mathrm{OH})_{5}$ with octahedrally coordinated $\mathrm{Si}$ : a new ultrahighpressure hydrous phase. Am Min 105:1432-1435

Bindi L, Sinmyo R, Bykova E, Ovsyannikov SV, McCammon C, Kupenko I, Ismailova L, Dubrovinsky L, Xie X (2021) Discovery of elgoresyite, (Mg, $\mathrm{Fe})_{5} \mathrm{Si}_{2} \mathrm{O}_{9}$ : implications for novel iron-magnesium silicates in rocky planetary interiors. ACS Earth Space Chem 5(8):2124-2130

Binns RA, Davis RJ, Reed SJB (1969) Ringwoodite, Natural (Mg, Fe) ${ }_{2} \mathrm{SiO}_{4}$ spinel in the Tenham meteorite. Nature 221:943-944

Brenker FE, Nestola F, Brenker L, Peruzzo L, Harris JW (2021) Origin, properties, and structure of breyite: the second most abundant mineral inclusion in super-deep diamonds. Am Min 106:38-43

Britvin SN, Rudashevsky NS, Krivovichev SV, Burns PC, Polekhovsky YS (2002) Allabogdanite, $(\mathrm{Fe}, \mathrm{Ni})_{2} \mathrm{P}$, a new mineral from the Onello meteorite: the occurrence and crystal structure. Am Min 87:1245-1249

Britvin SN, Shilovskikh W, Pagano R, Vlasenko NS, Zaitsev AN, Krzhizhanovskaya MG, Lozhkin MS, Zolotarev AA, Gurzhiy VV (2019) Allabogdanite, the high-pressure polymorph of $(\mathrm{Fe}, \mathrm{Ni})_{2} \mathrm{P}$, a stishovite-grade indicator of impact processes in the Fe-Ni-P system. Sci Rep 9:1047

Bundy FP, Hall HT, Strong HM, Wentorfun RH (1955) Man-made diamonds. Nature 176:51-55

Bundy FP, Kasper JS (1967) Hexagonal diamond-a new form of carbon. J Chem Phys 46:3437-3446

Cavosie AJ, Erickson TM, Timms NE (2015) Nanoscale records of ancient shock deformation: Reidite $\left(\mathrm{ZrSiO}_{4}\right)$ in sandstone at the ordovician rock elm impact crater. Geology 43:315-318

Chalifoux WA, Tykwinski RR (2010) Synthesis of polyynes to model the spcarbon allotrope carbyne. Nat Chem 2:967-971

Chao ECT, Shoemaker EM, Madsen BM (1960) First natural occurrence of coesite. Science 132:220-222

Chao ECT, Fahey JJ, Littler J, Milton DJ (1962) Stishovite, $\mathrm{SiO}_{2}$, a very high pressure new mineral from meteor crater, Arizona. J Geophys Res 67:419-421

Chen M, Sharp TG, El Goresy A, Wopenka B, Xie X (1996) The majoritepyrope + magnesiowüstite assemblage: constraints on the history of shock veins in chondrites. Science 271:1570-1573 
Chen M, Shu J, Mao H-k, Xie X, Hemley RJ (2003a) Natural occurrence and synthesis of two new postspinel polymorphs of chromite. Proc Natl Acad Sci USA 100:14651-14654

Chen M, Shu J, Xie X, Mao H-k (2003b) Natural $\mathrm{CaTi}_{2} \mathrm{O}_{4}$-structured FeCr $\mathrm{O}_{4}$ polymorph in the Suizhou meteorite and its significance in mantle mineralogy. Geochim Cosmochim Acta 67:3937-3942

Chen M, Chen J, Xie X, Xu J (2007) A microstructural investigation of natural lamellar ringwoodite in olivine of the shocked Sixiangkou chondrite. Earth Planet Sci Lett 264:277-283

Chen M, Shu J, Mao H-k (2008) Xieite, a new mineral of high-pressure $\mathrm{FeCr}_{2} \mathrm{O}_{4}$ polymorph. Sci Bull 53:3341-3345

Chen M, Yin F, Li X, Xie X, Xiao W, Tan D (2013) Natural occurrence of reidite in the Xiuyan crater of China. Meteorit Planet Sci 48:796-805

Chen M, Shu J, Xie X, Tan D (2019) Maohokite, a post-spinel polymorph of $\mathrm{MgFe}_{2} \mathrm{O}_{4}$ in shocked gneiss from the Xiuyan crater in China. Meteorit Planet Sci 54:495-502

Coes $L$ (1953) A new dense crystalline silica. Science 118:131

Collerson KD, Hapugoda S, Kamber BS, Williams Q (2000) Rocks from the mantle transition zone: majorite-bearing xenoliths from malaita, southwest pacific. Science 288:1215-1223

Cox MA, Cavosie AJ, Bland PA, Miljković K, Wingate MT (2018) Microstructural dynamics of central uplifts: reidite offset by zircon twins at the Woodleigh impact structure, Australia. Geology 46:983-986

DeCarli PS, Jamieson JC (1961) Formation of diamond by explosive shock. Science 134:92-92

DeCarli PS, Milton DJ (1965) Stishovite: synthesis by shock wave. Science 147:144

Dera P, Prewitt CT, Boctor NZ, Hemley RJ (2002) Characterization of a highpressure phase of silica from the Martian meteorite Shergotty. Am Min 87:1018-1023

Dera P, Lavina B, Borkowski LA, Prakapenka VB, Sutton SR, Rivers ML, Downs RT, Boctor NZ, Prewitt CT (2008) High-pressure polymorphism of $\mathrm{Fe}_{2} \mathrm{P}$ and its implications for meteorites and Earth's core. Geophys Res Lett 35:L10301

Dubrovinsky L, El Goresy A, Gillet P, Wu X, Simionivici A (2009) A novel natural shock-induced high-pressure polymorph of $\mathrm{FeTiO}_{3}$ with the Li-Niobate structure from the Ries crater Germany. Meteorit Planet Sci 44:A64

El Goresy A, Donnay G (1968) A new allotropic form of carbon from the Ries crater. Science 161:363-364

El Goresy A, Dubrovinsky L, Sharp TG, Saxena SK, Chen M (2000) A monoclinic post-stishovite polymorph of silica in the shergotty meteorite. Science 288:1632-1635

El Goresy A, Chen M, Dubrovinsky L, Gillet P, Graup G (2001) An ultradense polymorph of rutile with seven-coordinated titanium from the Ries crater. Science 293:1467-1470

El Goresy A, Dubrovinsky LS, Gillet P, Mostefaoui S, Graup G, Drakopoulos M, Simionovici AS, Swamy V, Masaitis VL (2003) A new natural, super-hard, transparent polymorph of carbon from the Popigai impact crater, Russia. C R Geosci 335:889-898

El Goresy A, Dera P, Sharp TG, Prewitt CT, Chen M, Dubrovinsky L, Wopenka B, Boctor NZ, Hemley RJ (2008) Seifertite, a dense orthorhombic polymorph of silica from the Martian meteorites Shergotty and Zagami. Eur J Miner 20:523-528

El Goresy A, Dubrovinsky L, Gillet P, Graup G, Chen M (2010) Akaogiite: An ultra-dense polymorph of $\mathrm{TiO}_{2}$ with the baddeleyite-type structure, in shocked garnet gneiss from the Ries crater, Germany. Am Min 95:892-895

El Goresy A, Gillet P, Miyahara M, Ohtani E, Ozawa S, Beck P, Montagnac G (2013) Shock-induced deformation of shergottites: shock-pressures and perturbations of magmatic ages on Mars. Geochim Cosmochim Acta 101:233-262

Erickson TM, Pearce MA, Reddy SM, Timms NE, Cavosie AJ, Bourdet J, Rickard WD, Nemchin AA (2017) Microstructural constraints on the mechanisms of the transformation to reidite in naturally shocked zircon. Contrib Mineral Petrol 172:6

Finger LW, Hazen RM, Zhang J, Ko J, Navrotsky A (1993) The effect of Fe on the crystal structure of wadsleyite $\beta-\left(\mathrm{Mg}_{1-x} \mathrm{Fe}_{x}\right)_{2} \mathrm{SiO}_{4}, 0.00 \leq x \leq 0.40$. Phys Chem Miner 19:361-368

Fritz J, Greshake A (2009) High-pressure phases in an ultramafic rock from Mars. Earth Planet Sci Lett 288:619-623
Fritz J, Greshake A, Klementova M, Wirth R, Palatinus L, Trønnes RG, Fernandes VA, Böttger $U$, Ferrière $L$ (2020) Donwilhelmsite, $\left[\mathrm{CaAl}_{4} \mathrm{Si}_{2} \mathrm{O}_{11}\right]$, a new lunar high-pressure Ca-Al-silicate with relevance for subducted terrestrial sediments. Am Min 105:1704-1711

Frondel C, Marvin UB (1967) Lonsdaleite, a hexagonal polymorph of diamond. Nature 214:587-589

Fukimoto K, Miyahara M, Sakai T, Ohfuji H, Tomioka N, Kodama Y, Ohtani E, Yamaguchi A (2020) Back-transformation mechanisms of ringwoodite and majorite in an ordinary chondrite. Meteorit Planet Sci 55:1749-1763

Fukunaga K, Matsuda J-i, Nagao K, Miyamoto M, Ito K (1987) Noble-gas enrichment in vapour-growth diamonds and the origin of diamonds in ureilites. Nature 328:141-143

Gasparik T (1990) Phase relations in the transition zone. J Geophys Res Solid Earth 95:15751-15769

Gasparik T (2003) Phase diagrams for geoscientists. Springer, Berlin, p 462

Gautron L, Angel RJ, Miletich R (1999) Structural characterisation of the highpressure phase $\mathrm{CaAl}_{4} \mathrm{Si}_{2} \mathrm{O}_{11}$. Phys Chem Miner 27:47-51

German VN, Podurets MA, Trunin RF (1973) Shock compression of quartz to 90 GPa. J Exp Theor Phys 37:107-115

Gillet P, Chen M, Dubrovinsky L, El Goresy A (2000) Natural $\mathrm{NaAlSi}_{3} \mathrm{O}_{8}$-hollandite in the shocked sixiangkou meteorite. Science 287:1633-1636

Glass B, Liu S (2001) Discovery of high-pressure $\mathrm{ZrSiO}_{4}$ polymorph in naturally occurring shock-metamorphosed zircons. Geology 29:371-373

Glass BP, Liu S, Leavens PB (2002) Reidite: an impact-produced high-pressure polymorph of zircon found in marine sediments. Am Min 87:562-565

Goodrich CA, Scott ERD, Fioretti AM (2004) Ureilitic breccias: clues to the petrologic structure and impact disruption of the ureilite parent asteroid. Geochemistry 64:283-327

Grieve RAF, Langenhorst F, Stöffler D (1996) Shock metamorphism of quartz in nature and experiment: II Significance in geoscience. Meteorit Planet Sci 31:6-35

Guo Z, Li Y, Liu S, Xu H, Xie Z, Li S, Li X, Lin Y, Coulson IM, Zhang M (2020) Discovery of nanophase iron particles and high pressure clinoenstatite in a heavily shocked ordinary chondrite: Implications for the decomposition of pyroxene. Geochim Cosmochim Acta 272:276-286

Gurov EP, Gurova EP, Rakitskaya RB (1995) Impact diamonds in the craters of the Ukrainian shield. Meteoritics 30:515

Guyot F, Reynard B (1992) Pressure-induced structural modifications and amorphization in olivine compounds. Chem Geol 96:411-420

Hallis LJ, Huss GR, Nagashima K, Taylor GJ, Stöffler D, Smith CL, Lee MR (2017) Effects of shock and Martian alteration on Tissint hydrogen isotope ratios and water content. Geochim Cosmochim Acta 200:280-294

Heinemann S, Sharp TG, Seifert F, Rubie DC (1997) The cubic-tetragonal phase transition in the system majorite $\left(\mathrm{Mg}_{4} \mathrm{Si}_{4} \mathrm{O}_{12}\right)$ - pyrope $\left(\mathrm{Mg}_{3} \mathrm{Al}_{2} \mathrm{Si}_{3} \mathrm{O}_{12}\right)$, and garnet symmetry in the Earth's transition zone. Phys Chem Miner 24:206-221

Herd C, Walton EL, Ziegler K, Vaci Z, Agee C, Muttik N (2016) The Northwest Africa 10416 olivine-phyric Martian basalt: product of magma mixing, assimilation and alteration. In: 47th lunar and planetary science conference, p. 2527.pdf

Hollister LS, Bindi L, Yao N, Poirier GR, Andronicos CL, MacPherson GJ, Lin C, Distler WV, Eddy MP, Kostin A, Kryachko V, Steinhardt WM, Yudovskaya M, Eiler JM, Guan Y, Clarke JJ, Steinhardt PJ (2014) Impact-induced shock and the formation of natural quasicrystals in the early solar system. Nat Commun 5:4040

Holtstam D, Broman C, Söderhielm J, Zetterqvist A (2003) First discovery of stishovite in an iron meteorite. Meteorit Planet Sci 38:1579-1583

Hough RM, Gilmour I, Pillinger CT, Arden JW, Gilkess KWR, Yuan J, Milledge HJ (1995) Diamond and silicon carbide in impact melt rock from the Ries impact crater. Nature 378:41-44

Hu J, Sharp TG (2016) High-pressure phases in shock-induced melt of the unique highly shocked LL6 chondrite Northwest Africa 757. Meteorit Planet Sci 51:1353-1369

Hu J, Sharp TG (2017) Back-transformation of high-pressure minerals in shocked chondrites: low-pressure mineral evidence for strong shock. Geochim Cosmochim Acta 215:277-294

Hu S, Li Y, Gu L, Tang X, Zhang T, Yamaguchi A, Lin Y, Changela H (2020) Discovery of coesite from the martian shergottite Northwest Africa 8657. Geochim Cosmochim Acta 286:404-417 
Imae N, Ikeda Y (2010) High-pressure polymorphs of magnesian orthopyroxene from a shock vein in the Yamato-000047 Iherzolitic shergottite. Meteorit Planet Sci 45:43-54

Inoue T, Weidner DJ, Northrup PA, Parise JB (1998) Elastic properties of hydrous ringwoodite ( $\gamma$-phase) in $\mathrm{Mg}_{2} \mathrm{SiO}_{4}$. Earth Planet Sci Lett 160:107-113

Irifune $T$ (1993) Phase transformations in the earth's mantle and subducting slabs: Implications for their compositions, seismic velocity and density structures and dynamics. Island Arc 2:55-71

Irifune T, Ringwood AE, Hibberson WO (1994) Subduction of continental crust and terrigenous and pelagic sediments: an experimental study. Earth Planet Sci Lett 126:351-368

Irifune T, Kurio A, Sakamoto S, Inoue T, Sumiya H (2003) Ultrahard polycrystalline diamond from graphite. Nature 421:599-600

Ito E, Matsui Y, Suito K, Kawai N (1974) Synthesis of $\mathrm{Y}-\mathrm{Mg}_{2} \mathrm{SiO}_{4}$. Phys Earth Planet Inter 8:342-344

Ito E, Matsui Y (1978) Synthesis and crystal-chemical characterization of $\mathrm{MgSiO}_{3}$ perovskite. Earth Planet Sci Lett 38:443-450

Ito $\mathrm{E}$, Yamada $\mathrm{H}$ (1982) Stability relations of silicate spinels, ilmenites, and perovskites. In: Akimoto S, Manghnani MH (eds) High-pressure research in geophysics. Center of Academic Publications, Tokyo, pp 405-419

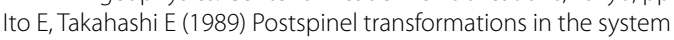
$\mathrm{Mg}_{2} \mathrm{SiO}_{4}-\mathrm{Fe}_{2} \mathrm{SiO}_{4}$ and some geophysical implications. J Geophys Res Solid Earth 94:10637-10646

Ito S, Suzuki K, Inagaki M, Naka S (1980) High-pressure modifications of $\mathrm{CaAl}_{2} \mathrm{O}_{4}$ and $\mathrm{CaGa}_{2} \mathrm{O}_{4}$. Mater Res Bull 15:925-932

Jaret SJ, Woerner WR, Phillips BL, Ehm L, Nekvasil H, Wright SP, Glotch TD (2015) Maskelynite formation via solid-state transformation: evidence of infrared and X-ray anisotropy. J Geophys Res Planets 120:570-587

Jeanloz R (1979) Ringwoodite: complex aggregate misidentified as a highpressure spinel structure. In: 10th Lunar and planetary science conference, pp 619-621

Kaneko S, Miyahara M, Ohtani E, Arai T, Hirao N, Sato K (2015) Discovery of stishovite in Apollo 15299 sample. Am Min 100:1308-1311

Kato T, Kumazawa M (1985) Garnet phase of $\mathrm{MgSiO}_{3}$ filling the pyroxeneilmenite gap at very high temperature. Nature 316:803-805

Kato T, Nakata N, Ohtani E, Onuma K (1998) Melting experiments on the forsterite-pyrope system at 8 and $13.5 \mathrm{GPa}$. Phys Earth Planet Inter 107:97-102

Kato Y, Sekine T, Kayama M, Miyahara M, Yamaguchi A (2017) High-pressure polymorphs in Yamato-790729 L6 chondrite and their significance for collisional conditions. Meteorit Planet Sci 52:2570-2585

Kawai N, Tachimori M, Ito $\mathrm{E}$ (1974) A high pressure hexagonal form of $\mathrm{MgSiO}_{3}$. Proc Jpn Acad 50:378-380

Kayama M, Tomioka N, Ohtani E, Seto Y, Nagaoka H, Götze J, Miyake A, Ozawa S, Sekine T, Miyahara M, Tomeoka K, Matsumoto M, Shoda N, Hirao N, Kobayashi T (2018) Discovery of moganite in a lunar meteorite as a trace of $\mathrm{H}_{2} \mathrm{O}$ ice in the Moon's regolith. Sci Adv 4:eaar4378

Kieffer SW (1971) Shock metamorphism of the Coconino sandstone at meteor crater, Arizona. J Geophys Res 76:5449-5473

Kimura M, Chen M, Yoshida Y, El Goresy A, Ohtani E (2004) Back-transformation of high-pressure phases in a shock melt vein of an $\mathrm{H}$-chondrite during atmospheric passage: implications for the survival of high-pressure phases after decompression. Earth Planet Sci Lett 217:141-150

Kimura M, Yamaguchi A, Miyahara M (2017) Shock-induced thermal history of an EH3 chondrite, Asuka 10164. Meteorit Planet Sci 52:24-35

Kitamura M, Goto T, Syono Y (1977) Intergrowth textures of diaplectic glass and crystal in shock-loaded P-anorthite. Contrib Mineral Petrol 61:299-304

Koeberl C, Masaitis VL, Shafranovsky Gl, Gilmour I, Langenhorst F, Schrauder M (1997) Diamonds from the Popigai impact structure, Russia. Geology 25:967-970

Kohlstedt DL, Keppler H, Rubie DC (1996) Solubility of water in the $a, \beta$ and $\gamma$ phases of $(\mathrm{Mg}, \mathrm{Fe})_{2} \mathrm{SiO}_{4}$. Contrib Mineral Petrol 123:345-357

Kring DA, Tikoo SM, Schmieder M, Riller U, Rebolledo-Vieyra M, Simpson SL, Osinski GR, Gattacceca J, Wittmann A, Verhagen CM, Cockell CS, Coolen MJL, Longstaffe FJ, Gulick SPS, Morgan JV, Bralower TJ, Chenot E, Christeson GL, Claeys P, Ferrière L, Gebhardt C, Goto K, Green SL, Jones H, Lofi J, Lowery CM, Ocampo-Torres R, Perez-Cruz L, Pickersgill AE, Poelchau MH, Rae ASP, Rasmussen C, Sato H, Smit J, Tomioka N, Urrutia-Fucugauchi J, Whalen MT, Xiao L, Yamaguchi KE (2020) Probing the hydrothermal system of the Chicxulub impact crater. Sci Adv 6:eaaz3053
Ksanda CJ, Henderson EP (1939) Identification of diamond in the canyon diablo iron. Am Min 24:677-680

Kubo T, Kimura M, Kato T, Nishi M, Tominaga A, Kikegawa T, Funakoshi K (2010) Plagioclase breakdown as an indicator for shock conditions of meteorites. Nat Geosci 3:41-45

Kubo T, Kato T, Higo Y, Funakoshi K-i (2015) Curious kinetic behavior in silica polymorphs solves seifertite puzzle in shocked meteorite. Sci Adv 1:1500075

Kubo T, Kono M, Imamura M, Kato T, Uehara S, Kondo T, Higo Y, Tange Y, Kikegawa T (2017) Formation of a metastable hollandite phase from amorphous plagioclase: a possible origin of lingunite in shocked chondritic meteorites. Phys Earth Planet Inter 272:50-57

Kunz GF (1888) Diamonds in meteorites. Science 11:118-119

Kusaba K, Syono Y, Kikuchi M, Fukuoka K (1985) Shock behavior of zircon: phase transition to scheelite structure and decomposition. Earth Planet Sci Lett 72:433-439

Kuwayama Y, Hirose K, Sata N, Ohishi Y (2005) The pyrite-type high-pressure form of silica. Science 309:923-925

Langenhorst F, Poirier J-P (2000) Anatomy of black veins in Zagami: clues to the formation of high-pressure phases. Earth Planet Sci Lett 184:37-55

Langenhorst F (2002) Shock metamorphism of some minerals: basic introduction and microstructural observations. Bull Czech Geol Surv 77:265-282

Lin C, Hollister LS, MacPherson GJ, Bindi L, Ma C, Andronicos CL, Steinhardt PJ (2017) Evidence of cross-cutting and redox reaction in Khatyrka meteorite reveals metallic-Al minerals formed in outer space. Sci Rep 7:1637

Litasov KD, Bekker TB, Sagatov NE, Gavryushkin PN, Krinitsyn PG, Kuper KE (2020) $(\mathrm{Fe}, \mathrm{Ni})_{2} \mathrm{P}$ allabogdanite can be an ambient pressure phase in iron meteorites. Sci Rep 10:8956

Liu L-G (1974) Silicate perovskite from phase transformations of pyrope-garnet at high pressure and temperature. Geophys Res Lett 1:277-280

Liu L-G (1975) Post-oxide phases of forsterite and enstatite. Geophys Res Lett 2:417-419

Liu L-G, Ringwood AE (1975) Synthesis of a perovskite-type polymorph of $\mathrm{CaSiO}_{3}$. Earth Planet Sci Lett 28:209-211

Liu L-G (1976) The high-pressure phases of $\mathrm{MgSiO}_{3}$. Earth Planet Sci Lett 31:200-208

Liu L-G (1978) High-pressure phase transformations of albite, jadeite and nepheline. Earth Planet Sci Lett 37:438-444

Liu L-G, El Gorsey A (2007) High-pressure phase transitions of the feldspars, and further characterization of lingunite. Int Geol Rev 49:854-860

Liu M, Artyukhov VI, Lee H, Xu F, Yakobson BI (2013) Carbyne from first principles: chain of $\mathrm{C}$ atoms, a nanorod or a nanorope. ACS Nano 7:10075-10082

Liu X (2006) Phase relations in the system $\mathrm{KAISi}_{3} \mathrm{O}_{8}-\mathrm{NaAlSi}_{3} \mathrm{O}_{8}$ at high pressure-high temperature conditions and their implication for the petrogenesis of lingunite. Earth Planet Sci Lett 246:317-325

Lowery CM, Bralower TJ, Owens JD, Rodríguez-Tovar FJ, Jones H, Smit J, Whalen MT, Claeys P, Farley K, Gulick SP (2018) Rapid recovery of life at ground zero of the end-Cretaceous mass extinction. Nature 558:288-291

Ma C, Tschauner O, Beckett JR, Liu Y, Rossman GR, Zhuravlev K, Prakapenka V, Dera P, Taylor LA (2015) Tissintite, ( $\mathrm{Ca}, \mathrm{Na}, \square) \mathrm{AlSi}_{2} \mathrm{O}_{6}$, a highly-defective, shock-induced, high-pressure clinopyroxene in the Tissint martian meteorite. Earth Planet Sci Lett 422:194-205

Ma C, Tschauner O, Beckett JR, Liu Y, Rossman GR, Sinogeikin SV, Smith JS, TayIor LA (2016) Ahrensite, $y-\mathrm{Fe}_{2} \mathrm{SiO}_{4}$, a new shock-metamorphic mineral from the Tissint meteorite: implications for the tissint shock event on Mars. Geochim Cosmochim Acta 184:240-256

Ma C, Tschauner O (2017) Zagamiite, IMA 2015-022a. CNMNC newsletter No. 36. Min M 81:403-409

Ma C, Tschauner O, Beckett JR, Rossman GR, Prescher C, Prakapenka VB, Bechtel $\mathrm{HA}$, MacDowell A (2018) Liebermannite, $\mathrm{KAISi}_{3} \mathrm{O}_{8}$, a new shock-metamorphic, high-pressure mineral from the Zagami Martian meteorite. Meteorit Planet Sci 53:50-61

Ma C, Tschauner O, Beckett J (2019a) A closer look at Martian meteorites: Discovery of the new mineral Zagamiite, $\mathrm{CaAl}_{2} \mathrm{Si}_{3 \cdot 5} \mathrm{O}_{11}$, a shock-metamorphic, high-pressure, calcium aluminosilicate. In: Ninth international conference on Mars, 6138.pdf

Ma C, Tschauner O, Beckett JR, Liu Y, Greenberg E, Prakapenka VB (2019b) Chenmingite, $\mathrm{FeCr}_{2} \mathrm{O}_{4}$ in the $\mathrm{CaFe}_{2} \mathrm{O}_{4}$-type structure, a shock-induced, high-pressure mineral in the Tissint martian meteorite. Am Min 104:1521-1525 
Ma C, Tschauner O, Bindi L, Beckett JR, Xie X (2019c) A vacancy-rich, partially inverted spinelloid silicate, ( $\mathrm{Mg}, \mathrm{Fe}, \mathrm{Si})_{2}(\mathrm{Si}, \square) \mathrm{O}_{4}$, as a major matrix phase in shock melt veins of the Tenham and Suizhou L6 chondrites. Meteorit Planet Sci 54:1907-1918

Ma C, Tschauner O, Kong M, Beckett J, Greenberg E, Prakapenka V, Lee Y (2020) Discovery of a highly-defective, shock-induced, high-pressure albitic jadeite, $\left(\mathrm{Na}, \mathrm{Ca}, \square_{1 / 4}\right)\left(\mathrm{Al}, \mathrm{Si}_{1}\right) \mathrm{Si}_{2} \mathrm{O}_{6}$ : natural occurrence of a clinopyroxene with excess Si. In: 51st Lunar and planetary science conference, 1712. pdf

Ma C, Beckett J, Prakapenka V (2021a) Discovery of new high-pressure mineral Tschaunerite, $\left(\mathrm{Fe}^{2+}\right)\left(\mathrm{Fe}^{2+} \mathrm{Ti}^{4+}\right) \mathrm{O}_{4}$, a shock-induced, post-spinel phase in the Martian meteorite Shergotty. In: 52nd lunar and planetary science conference, 1720.pdf

Ma C, Tschauner O, Beckett J, Prakapenka V (2021 b) Discovery of Feiite $\left(\mathrm{Fe}^{2+}{ }_{2}\left(\mathrm{Fe}^{2+} \mathrm{Ti}^{4+}\right) \mathrm{O}_{5}\right)$ and Liuite $\left(\mathrm{GdFeO}_{3}\right.$-Type $\left.\mathrm{FeTiO}_{3}\right)$, two new shockinduced, high-pressure minerals in the Martian meteorite Shergotty. In: 52nd lunar and planetary science conference, 1681.pdf

MacPherson GJ, Andronicos CL, Bindi L, Distler W, Eddy MP, Eiler JM, Guan Y, Hollister LS, Kostin A, Kryachko V, Steinhardt WM, Yudovskaya M, Steinhardt PJ (2013) Khatyrka, a new CV3 find from the Koryak Mountains, Eastern Russia. Meteorit Planet Sci 48:1499-1514

Madon M, Poirier JP (1983) Transmission electron microscope observation of $\alpha, \beta$ and $\gamma\left(\mathrm{Mg}, \mathrm{Fe}_{2} \mathrm{SiO}_{4}\right.$ in shocked meteorites: planar defects and polymorphic transitions. Phys Earth Planet Inter 33:31-44

Malone L, Boonsue S, Spray J, Wittmann A (2010) Zircon-reidite relations in breccias from the Chesapeake Bay impact structure. In: 41st lunar and planetary science conference, 2286.pdf

Martini J (1978) Coesite and stishovite in the Vredefort dome, South Africa. Nature 272:715-717

Martini J (1991) The nature, distribution and genesis of the coesite and stishovite associated with the pseudotachylite of the Vredefort Dome, South Africa. Earth Planet Sci Lett 103:285-300

Maruyama S, Tomioka N (2011) Ca-Al-Fe-rich inclusion in the Vigarano CV3 chondrite. Meteorit Planet Sci 46:690-700

Mason B, Nelen J, White JS (1968) Olivine-garnet transformation in a meteorite. Science 160:66-67

Meier MMM, Bindi L, Heck PR, Neander Al, Spring NH, Riebe MEI, Maden C, Baur H, Steinhardt PJ, Wieler R, Busemann H (2018) Cosmic history and a candidate parent asteroid for the quasicrystal-bearing meteorite Khatyrka. Earth Planet Sci Lett 490:122-131

Mikouchi T, Zolensky M, Ivanova M, Tachikawa O, Komatsu M, Le L, Gounelle M (2009) Dmitryivanovite: A new high-pressure calcium aluminum oxide from the Northwest Africa $470 \mathrm{CH} 3$ chondrite characterized using electron backscatter diffraction analysis. Am Min 94:746-750

Milton DJ, de Carli PS (1963) Maskelynite: formation by explosive shock. Science 140:670-671

Ming LC, Kim YH, Manghnani MH, Usha-Devi S, Ito E, Xie HS (1991) Back transformation and oxidation of $(\mathrm{Mg}, \mathrm{Fe})_{2} \mathrm{SiO}_{4}$ spinels at high temperatures. Phys Chem Miner 18:171-179

Miyahara M, El Goresy A, Ohtani E, Nagase T, Nishijima M, Vashaei Z, Ferroir T, Gillet P, Dubrovinsky L, Simionovici A (2008) Evidence for fractional crystallization of wadsleyite and ringwoodite from olivine melts in chondrules entrained in shock-melt veins. Proc Natl Acad Sci USA 105:8542-8547

Miyahara M, El Goresy A, Ohtani E, Kimura M, Ozawa S, Nagase T, Nishijima M (2009) Fractional crystallization of olivine melt inclusion in shockinduced chondritic melt vein. Phys Earth Planet Inter 177:116-121

Miyahara M, Ohtani E, Kimura M, El Goresy A, Ozawa S, Nagase T, Nishijima M, Hiraga K (2010) Coherent and subsequent incoherent ringwoodite growth in olivine of shocked L6 chondrites. Earth Planet Sci Lett 295:321-327

Miyahara M, Ohtani E, Kimura M, Ozawa S, Nagase T, Nishijima M, Hiraga K (2011a) Evidence for multiple dynamic events and subsequent decompression stage recorded in a shock vein. Earth Planet Sci Lett 307:361-368

Miyahara M, Ohtani E, Ozawa S, Kimura M, El Goresy A, Sakai T, Nagase T, Hiraga $\mathrm{K}$, Hirao N, Ohishi Y (2011 b) Natural dissociation of olivine to (Mg, Fe) $\mathrm{SiO}_{3}$ perovskite and magnesiowustite in a shocked Martian meteorite. Proc Natl Acad Sci USA 108:5999-6003
Miyahara M, Kaneko S, Ohtani E, Sakai T, Nagase T, Kayama M, Nishido H, Hirao N (2013a) Discovery of seifertite in a shocked lunar meteorite. Nat Commun 4:1737

Miyahara M, Ozawa S, Ohtani E, Kimura M, Kubo T, Sakai T, Nagase T, Nishijima M, Hirao N (2013b) Jadeite formation in shocked ordinary chondrites. Earth Planet Sci Lett 373:102-108

Miyahara M, Ohtani E, Yamaguchi A, Ozawa S, Sakai T, Hirao N (2014) Discovery of coesite and stishovite in eucrite. Proc Natl Acad Sci USA 111:10939-10942

Miyahara M, Ohtani E, El Goresy A, Lin Y, Feng L, Zhang J-C, Gillet P, Nagase T, Muto J, Nishijima M (2015) Unique large diamonds in a ureilite from Almahata Sitta $2008 \mathrm{TC}_{3}$ asteroid. Geochim Cosmochim Acta 163:14-26

Miyahara M, Ohtani E, El Goresy A, Ozawa S, Gillet P (2016) Phase transition processes of olivine in the shocked Martian meteorite tissint: clues to origin of ringwoodite-, bridgmanite- and magnesiowüstite-bearing assemblages. Phys Earth Planet Inter 259:18-28

Miyahara M, Ohtani E, Yamaguchi A (2017) Albite dissociation reaction in the Northwest Africa 8275 shocked LL chondrite and implications for its impact history. Geochim Cosmochim Acta 217:320-333

Miyahara M, Ohtani E, Nishijima M, El Goresy A (2019) Olivine melting at high pressure condition in the chassignite Northwest Africa 2737. Phys Earth Planet Inter 291:1-11

Miyahara M, Yamaguchi A, Saitoh M, Fukimoto K, Sakai T, Ohfuji H, Tomioka N, Kodama Y, Ohtani E (2020) Systematic investigations of high-pressure polymorphs in shocked ordinary chondrites. Meteorit Planet Sci 55:2619-2651

Miyahara M, Yamaguchi A, Ohtani E, Tomioka N, Kodama Y (2021) Complicated pressure-temperature path recorded in the eucrite Padvarninkai. Meteorit Planet Sci. https://doi.org/10.1111/maps.13724

Mizutani H, Takagi Y, Kawakami S-I (1990) New scaling laws on impact fragmentation. Icarus 87:307-326

Moore RO, Gurney JJ (1985) Pyroxene solid solution in garnets included in diamond. Nature 318:553-555

Morgan JV, Gulick SPS, Bralower T, Chenot E, Christeson G, Claeys P, Cockell C, Collins GS, Coolen MJL, Ferrière L, Gebhardt C, Goto K, Jones H, Kring DA, Le Ber E, Lofi J, Long X, Lowery C, Mellett C, Ocampo-Torres R, Osinski GR, Perez-Cruz L, Pickersgill A, Poelchau M, Rae A, Rasmussen C, Rebolledo-Vieyra M, Riller U, Sato H, Schmitt DR, Smit J, Tikoo S, Tomioka N, Urrutia-Fucugauchi J, Whalen M, Wittmann A, Yamaguchi KE, Zylberman W (2016) The formation of peak rings in large impact craters. Science 354:878-882

Morrison SM, Hazen RM (2021) An evolutionary system of mineralogy, Part IV: planetesimal differentiation and impact mineralization (4566 to 4560 Ma). Am Min 106:730-761

Murakami M, Hirose K, Ono S, Ohishi Y (2003) Stability of $\mathrm{CaCl}_{2}$-type and a-PbO - -type $\mathrm{SiO}_{2}$ at high pressure and temperature determined by in-situ X-ray measurements. Geophys Res Lett 30:1207

Murayama JK, Nakai S, Kato M, Kumazawa M (1986) A dense polymorph of $\mathrm{Ca}_{3}\left(\mathrm{PO}_{4}\right)_{2}:$ a high pressure phase of apatite decomposition and its geochemical significance. Phys Earth Planet Inter 44:293-303

Nabiei F, Badro J, Dennenwaldt T, Oveisi E, Cantoni M, Hebert C, El Goresy A, Barrat JA, Gillet P (2018) A large planetary body inferred from diamond inclusions in a ureilite meteorite. Nat Commun 9:1327

Nagai T, Ohtaka O, Yamanaka T (1997) Kinetic studies of the a-quartz-coesite transformation of $\mathrm{SiO}_{2}$. Mineral J 19:147-154

Nakamuta Y, Aoki Y (2000) Mineralogical evidence for the origin of diamond in ureilites. Meteorit Planet Sci 35:487-493

Nakamuta Y, Toh S (2013) Transformation of graphite to lonsdaleite and diamond in the Goalpara ureilite directly observed by TEM. Am Min 98:574-581

Nakatsuka A, Yoshiasa A, Yamanaka T, Ohtaka O (1999) Symmetry change of majorite solid-solution in the system $\mathrm{Mg}_{3} \mathrm{Al}_{2} \mathrm{Si}_{3} \mathrm{O}_{12}-\mathrm{MgSiO}_{3}$. Am Min 84:1135-1143

Németh P, Garvie LAJ, Aoki T, Dubrovinskaia N, Dubrovinsky L, Buseck PR (2014) Lonsdaleite is faulted and twinned cubic diamond and does not exist as a discrete material. Nat Commun 5:5447

Németh P, Garvie LAJ (2020) Extraterrestrial, shock-formed, cage-like nanostructured carbonaceous materials. Am Min 105:276-281

Nestola F, Burnham AD, Peruzzo L, Tauro L, Alvaro M, Walter MJ, Gunter M, Anzolini C, Kohn SC (2016) Tetragonal almandine-pyrope phase, TAPP. finally a name for it, the new mineral jeffbenite. Min M 80:1219-1232 
Nestola F, Korolev N, Kopylova M, Rotiroti N, Pearson DG, Pamato MG, Alvaro M, Peruzzo L, Gurney JJ, Moore AE, Davidson J (2018) $\mathrm{CaSiO}_{3}$ perovskite in diamond indicates the recycling of oceanic crust into the lower mantle. Nature 555:237-241

Nestola F, Goodrich CA, Morana M, Barbaro A, Jakubek RS, Christ O, Brenker FE, Domeneghetti MC, Dalconi MC, Alvaro M, Fioretti AM, Litasov KD, Fries MD, Leoni M, Casati NPM, Jenniskens P, Shaddad MH (2020) Impact shock origin of diamonds in ureilite meteorites. Proc Natl Acad Sci USA 117:25310-25318

Nishio-Hamane D, Shimizu A, Nakahira R, Niwa K, Sano-Furukawa A, Okada T, Yagi T, Kikegawa T (2010) The stability and equation of state for the cotunnite phase of $\mathrm{TiO}_{2}$ up to $70 \mathrm{GPa}$. Phys Chem Miner 37:129-136

Ohfuji H, Irifune T, Litasov KD, Yamashita T, Isobe F, Afanasiev VP, Pokhilenko NP (2015) Natural occurrence of pure nano-polycrystalline diamond from impact crater. Sci Rep 5:14702

Ohira I, Ohtani E, Sakai T, Miyahara M, Hirao N, Ohishi Y, Nishijima M (2014) Stability of a hydrous $\delta$-phase, $\mathrm{AlOOH}-\mathrm{MgSiO}_{2}(\mathrm{OH})_{2}$, and a mechanism for water transport into the base of lower mantle. Earth Planet Sci Lett 401:12-17

Ohtani E, Kagawa N, Fujino K (1991) Stability of majorite (Mg, Fe)SiO 3 at high pressures and $1800^{\circ} \mathrm{C}$. Earth Planet Sci Lett 102:158-166

Ohtani E, Moriwaki K, Kato T, Onuma K (1998) Melting and crystal-liquid partitioning in the system $\mathrm{Mg}_{2} \mathrm{SiO}_{4}-\mathrm{Fe}_{2} \mathrm{SiO}_{4}$ to $25 \mathrm{GPa}$. Phys Earth Planet Inter 107:75-82

Ohtani E, Kimura Y, Kimura M, Takata T, Kondo T, Kubo T (2004) Formation of high-pressure minerals in shocked L6 chondrite Yamato 791384 : constraints on shock conditions and parent body size. Earth Planet Sci Lett 227:505-515

Ohtani E, Ozawa S, Miyahara M, Ito Y, Mikouchi T, Kimura M, Arai T, Sato K, Hiraga K (2011) Coesite and stishovite in a shocked lunar meteorite, Asuka-881757, and impact events in lunar surface. Proc Natl Acad Sci USA 108:463-466

Okuchi T, Seto Y, Tomioka N, Matsuoka T, Albertazzi B, Hartley NJ, Inubushi Y, Katagiri K, Kodama R, Pikuz TA, Purevjav N, Miyanishi K, Sato T, Sekine T, Sueda K, Tanaka KA, Tange Y, Togashi T, Umeda Y, Yabuuchi T, Yabashi M, Ozaki N (2021) Ultrafast olivine-ringwoodite transformation during shock compression. Nat Commun 12:4305

Ono S, Tange Y, Katayama I, Kikegawa T (2004) Equations of state of $\mathrm{ZrSiO}_{4}$ phases in the upper mantle. Am Min 89:185-188

Ozawa S, Ohtani E, Miyahara M, Suzuki A, Kimura M, Ito Y (2009) Transformation textures, mechanisms of formation of high-pressure minerals in shock melt veins of $L 6$ chondrites, and pressure-temperature conditions of the shock events. Meteorit Planet Sci 44:1771-1786

Ozawa S, Miyahara M, Ohtani E, Koroleva ON, Ito Y, Litasov KD, Pokhilenko NP (2014) Jadeite in Chelyabinsk meteorite and the nature of an impact event on its parent body. Sci Rep 4:5033

Pan B, Xiao J, Li J, Liu P, Wang C, Yang G (2015) Carbyne with finite length: The one-dimensional sp carbon. Sci Adv 1:e1500857

Pang R-L, Harries D, Pollok K, Zhang A-C, Langenhorst F (2018) Vestaite, $\left(\mathrm{Ti}^{4+} \mathrm{Fe}^{2+}\right) \mathrm{Ti}_{3}{ }^{4+} \mathrm{O}_{9}$, a new mineral in the shocked eucrite Northwest Africa 8003. Am Min 103:1502-1511

Pang RL, Zhang AC, Wang SZ, Wang RC, Yurimoto H (2016) High-pressure minerals in eucrite suggest a small source crater on Vesta. Sci Rep 6:26063

Papike JJ (eds) (2018) Planetary materials. In: Reviews in mineralogy and geochemistry 36. Walter de Gruyter GmbH \& Co KG, New Mexico

Pearson DG, Brenker FE, Nestola F, McNeill J, Nasdala L, Hutchison MT, Matveev S, Mather K, Silversmit G, Schmitz S, Vekemans B, Vincze L (2014) Hydrous mantle transition zone indicated by ringwoodite included within diamond. Nature 507:221-224

Perrillat JP, Daniel I, Lardeaux JM, Cardon H (2003) Kinetics of the coesitequartz transition: application to the exhumation of ultrahigh-pressure rocks. J Petrol 44:773-788

Price GD, Putnis A, Agrell SO, Smith DGW (1983) Wadsleyite, natural beta - $(\mathrm{Mg}, \mathrm{Fe})_{2} \mathrm{SiO}_{4}$ from the Peace River meteorite. Can Mineral 21:29-35

Putnis A, Price GD (1979) High-pressure $\left(\mathrm{Mg}, \mathrm{Fe}_{2} \mathrm{SiO}_{4}\right.$ phases in the Tenham chondritic meteorite. Nature 280:217-218

Riller U, Poelchau MH, Rae AS, Schulte FM, Collins GS, Melosh HJ, Grieve RA, Morgan JV, Gulick SP, Lofi J (2018) Rock fluidization during peak-ring formation of large impact structures. Nature 562:511-518
Ringwood AE (1958a) The constitution of the mantle-II: further data on the olivine-spinel transition. Geochim Cosmochim Acta 15:18-29

Ringwood AE (1958b) The constitution of the mantle-l: thermodynamics of the olivine-spinel transition. Geochim Cosmochim Acta 13:303-321

Ringwood AE, Major A (1966a) Synthesis of $\mathrm{Mg}_{2} \mathrm{SiO}_{4}-\mathrm{Fe}_{2} \mathrm{SiO}_{4}$ spinel solid solutions. Earth Planet Sci Lett 1:241-245

Ringwood AE, Major A (1966b) High-pressure transformations in pyroxenes. Earth Planet Sci Lett 1:351-357

Ringwood AE, Reid AF, Wadsley AD (1967) High-pressure $\mathrm{KAISi}_{3} \mathrm{O}_{8}$, an aluminosilicate with sixfold coordination. Acta Crystallogr 23:1093-1095

Ringwood AE, Major A (1970) The system $\mathrm{Mg}_{2} \mathrm{SiO}_{4} \cdot \mathrm{Fe}_{2} \mathrm{SiO}_{4}$ at high pressures and temperatures. Phys Earth Planet Inter 3:89-108

Rucks MJ, Whitaker ML, Glotch TD, Parise JB, Jaret SJ, Catalano T, Dyar MD (2018) Making tissintite: mimicking meteorites in the multi-anvil. Am Min 103:1516-1519

Satta N. (2021) High pressure minerals in the Earth and Moon: understanding the lunar impact history and Earth's deep water cycle. Doctoral thesis, Bayreuth, https://doi.org/10.15495/EPub_UBT_00005517

Sato H, Endo S, Sugiyama M, Kikegawa T, Shimomura O, Kusaba K (1991) Baddeleyite-type high-pressure phase of $\mathrm{TiO}_{2}$. Science 251:786-788

Sharp TG, Lingemann CM, Dupas C, Stöffler D (1997) Natural occurrence of $\mathrm{MgSiO}_{3}$-ilmenite and evidence for $\mathrm{MgSiO}_{3}$-perovskite in a shocked $\mathrm{L}$ chondrite. Science 277:352-355

Sharp TG, El Goresy A, Wopenka B, Chen M (1999) A post-stishovite $\mathrm{SiO}_{2}$ polymorph in the meteorite Shergotty: implications for impact events. Science 284:1511-1513

Sharp TG, DeCarli PS (2006) Shock effects in meteorites. Univ of Arizona Press, Tucson, pp 653-677

Sharp TG, Xie Z, de Carli PS, Hu J (2015) A large shock vein in L chondrite roosevelt county 106: evidence for a long-duration shock pulse on the L chondrite parent body. Meteorit Planet Sci 50:1941-1953

Shinmei T, Tomioka N, Fujino K, Kuroda K, Irifune T (1999) In situ X-ray diffraction study of enstatite up to $12 \mathrm{GPa}$ and $1473 \mathrm{~K}$ and equations of state. Am Min 84:1588-1594

Smith JV, Mason B (1970) Pyroxene-garnet transformation in Coorara meteorite. Science 168:832-833

Smith PPK, Buseck PR (1982) Carbyne forms of carbon: do they exist? Science 216:984-986

Spray JG, Boonsue S (2018) Quartz-coesite-stishovite relations in shocked metaquartzites from the Vredefort impact structure, South Africa. Meteorit Planet Sci 53:93-109

Stähle V, Altherr R, Koch M, Nasdala L (2007) Shock-induced growth and metastability of stishovite and coesite in lithic clasts from suevite of the Ries impact crater (Germany). Contrib Mineral Petrol 155:457-472

Stähle V, Altherr R, Nasdala L, Ludwig T (2010) Ca-rich majorite derived from high-temperature melt and thermally stressed hornblende in shock veins of crustal rocks from the Ries impact crater (Germany). Contrib Mineral Petrol 161:275-291

Stähle V, Altherr R, Nasdala L, Trieloff M, Varychev A (2017) Majoritic garnet grains within shock-induced melt veins in amphibolites from the Ries impact crater suggest ultrahigh crystallization pressures between 18 and 9 GPa. Contrib Mineral Petrol. https://doi.org/10.1007/ s00410-017-1404-7

Stishov S, Popova S (1961) A new dense modification of silicon oxide. Geokhimiya 10:923-926

Stöffler D (1971) Coesite and stishovite in shocked crystalline rocks. J Geophys Res 76:5474-5488

Stöffler D (1984) Glasses formed by hypervelocity impact. J Non-Cryst Solids 67:465-502

Stöffler D, Ostertag R, Jammes C, Pfannschmidt G, Gupta PS, Simon S, Papike J, Beauchamp R (1986) Shock metamorphism and petrography of the Shergotty achondrite. Geochim Cosmochim Acta 50:889-903

Stöffler D, Klaus K, Scott E (1991) Shock metamorphism of ordinary chondrites. Geochim Cosmochim Acta 55:3845-3867

Stöffler D, Hamann C, Metzler K (2018) Shock metamorphism of planetary silicate rocks and sediments: proposal for an updated classification system. Meteorit Planet Sci 53:5-49

Suttle MD, Twegar K, Nava J, Spiess R, Spratt J, Campanale F, Folco L (2019) A unique $\mathrm{CO}$-like micrometeorite hosting an exotic $\mathrm{Al}-\mathrm{Cu}$-Fe-bearing 
assemblage — close affinities with the Khatyrka meteorite. Sci Rep 9:12426

Takenouchi A, Mikouchi T, Kobayashi T, Sekine T, Yamaguchi A, Ono H (2019) Fine-structures of planar deformation features in shocked olivine: a comparison between Martian meteorites and experimentally shocked basalts as an indicator for shock pressure. Meteorit Planet Sci 54:1990-2005

Tange Y, Takahashi E (2004) Stability of the high-pressure polymorph of zircon $\left(\mathrm{ZrSiO}_{4}\right)$ in the deep mantle. Phys Earth Planet Inter 143:223-229

Tani R, Tomioka N, Kayama M, Chang Y, Nishido H, Das K, Rae A, Ferrière L, Gulick SP, Morgan JV (2018) Microstructural observations of quartz from the basement rocks of the Chicxulub impact structure and shock pressure estimation. In: AGU fall meeting abstracts, PP51D-1167

Timms NE, Pearce MA, Erickson TM, Cavosie AJ, Rae AS, Wheeler J, Wittmann A, Ferrière L, Poelchau MH, Tomioka N (2019) New shock microstructures in titanite $\left(\mathrm{CaTiSiO}_{5}\right)$ from the peak ring of the Chicxulub impact structure. Mexico Contrib Mineral Petrol 174:38. https://doi.org/10. 1007/s00410-019-1565-7

Tiwari K, Ghosh S, Miyahara M, Ray D (2021) Shock-induced incongruent melting of olivine in Kamargaon L6 chondrite. Geophys Res Lett 48:e2021GL093592

Tomioka N, Fujino K (1997) Natural (Mg, $\mathrm{Fe}_{\mathrm{S}} \mathrm{SiO}_{3}$-ilmenite and -perovskite in the Tenham meteorite. Science 277:1084-1086

Tomioka N, Fujino K (1999) Akimotoite, (Mg, Fe)SiO ${ }_{3}$, a new silicate mineral of the ilmenite group in the Tenham chondrite. Am Min 84:267-271

Tomioka N, Mori H, Fujino K (2000) Shock-induced transition of $\mathrm{NaAlSi}_{3} \mathrm{O}_{8}$ feldspar into a hollandite structure in a L6 chondrite. Geophys Res Lett 27:3997-4000

Tomioka N, Fujino K, Ito E, Katsura T, Sharp T, Kato T (2002) Microstructures and structural phase transition in $\left(\mathrm{Mg}, \mathrm{Fe}_{\mathrm{SiO}} \mathrm{Si}_{3}\right.$ majorite. Eur J Miner 14:7-14

Tomioka N, Kimura M (2003) The breakdown of diopside to Ca-rich majorite and glass in a shocked $\mathrm{H}$ chondrite. Earth Planet Sci Lett 208:271-278

Tomioka N, Miyahara M, Ito M (2016) Discovery of natural $\mathrm{MgSiO}_{3}$ tetragonal garnet in a shocked chondritic meteorite. Sci Adv 2:e1501725

Tomioka N, Miyahara M (2017) High-pressure minerals in shocked meteorites. Meteorit Planet Sci 52:2017-2039

Tomioka N, Okuchi T (2017) A new high-pressure form of $\mathrm{Mg}_{2} \mathrm{SiO}_{4}$ highlighting diffusionless phase transitions of olivine. Sci Rep 7:17351

Tomioka N, Bindi L, Okuchi T, Miyahara M, litaka T, Li Z, Kawatsu T, Xie X, Purevjav N, Tani R, Kodama Y (2021) Poirierite, a dense metastable polymorph of magnesium iron silicate in shocked meteorites. Commun Earth Environ 2:16. https://doi.org/10.1038/s43247-020-00090-7

Tommasini S, Bindi L, Petrelli M, Asimow PD, Steinhardt PJ (2021) Trace element conundrum of natural quasicrystals. ACS Earth Space Chem 5:676-689

Treiman AH, Dyar MD, McCanta M, Noble SK, Pieters CM (2007) Martian dunite NWA 2737: petrographic constraints on geological history, shock events, and olivine color. J Geophys Res 112:E04002

Trieloff M, Jessberger EK, Herrwerth I, Hopp J, Fiéni C, Ghélis M, Bourot-Denise M, Pellas P (2003) Structure and thermal history of the $\mathrm{H}$-chondrite parent asteroid revealed by thermochronometry. Nature 422:502-506

Tsai A-P, Inoue A, Masumoto T (1987) Preparation of a new Al-Cu-Fe quasicrystal with large grain sizes by rapid solidification. J Mater Sci Lett 6:1403-1405

Tsai A-P, Inoue A, Masumoto T (1989) New decagonal Al-Ni-Fe and Al-Ni-Co alloys prepared by liquid quenching. Mater Trans 30:150-154

Tschauner O, Ma C, Beckett JR, Prescher C, Prakapenka VB, Rossman GR (2014) Mineralogy. Discovery of bridgmanite, the most abundant mineral in Earth, in a shocked meteorite. Science 346:1100-1102

Tschauner O, Huang S, Greenberg E, Prakapenka VB, Ma C, Rossman GR, Shen AH, Zhang D, Newville M, Lanzirotti A, Tait K (2018) Ice-VII inclusions in diamonds: evidence for aqueous fluid in Earth's deep mantle. Science 359:1136-1139

Tschauner O, Huang S, Yang S, Humayun M (2020a) Davemaoite, IMA 2020-012a. In: CNMNC newsletter 58. Eur J Mineral 32

Tschauner O, Ma C, Lanzirotti A, Newville MG (2020b) Riesite, a new high pressure polymorph of $\mathrm{TiO}_{2}$ from the ries impact structure. Minerals 10:78

Tschauner O, Ma C, Spray JG, Greenberg E, Prakapenka VB (2021) Stöfflerite, $(\mathrm{Ca}, \mathrm{Na})\left(\mathrm{Si}, \mathrm{A}_{1}\right)_{4} \mathrm{O}_{8}$ in the hollandite structure: a new high-pressure polymorph of anorthite from martian meteorite NWA 856. Am Min 106:650-655

Tschermak G (1872) Die meteoriten von Schergotty und Gopalpur. Sitzber Akad Wiss Wien Math Naturwiss Kl Abt I 65:122-146

Tschermak G (1883) Beitrag zur Klassifakation der Meteoriten. Sitzber Akad Wiss Wien Math Naturwiss Kl Abt I 88:347-371

Urey HC (1956) Diamonds, meteorites, and the origin of the Solar system. Astrophys J 124:623-637

van de Moortèle B, Reynard B, McMillan PF, Wilson M, Beck P, Gillet P, Jahn S (2007) Shock-induced transformation of olivine to a new metastable $\left(\mathrm{Mg}, \mathrm{Fe}_{2} \mathrm{SiO}_{4}\right.$ polymorph in Martian meteorites. Earth Planet Sci Lett 261:469-475

Vishnevsky S, Dolgov Y, Kovaleva L, Pal'chik N (1975) Stishovite from the Popigai structure rocks. Russ Geol Geophys 10:156-159

Vollmer C, Hoppe P, Brenker FE, Holzapfel C (2007) Stellar $\mathrm{MgSiO}_{3}$ perovskite: a shock-transformed stardust silicate found in a meteorite. Astrophys $J$ 666:L49-L52

Walter MJ, Kohn SC, Araujo D, Bulanova GP, Smith CB, Gaillou E, Wang J, Steele A, Shirey SB (2011) Deep mantle cycling of oceanic crust: evidence from diamonds and their mineral inclusions. Science 334:54-57

Walton EL, Sharp TG, Hu J, Filiberto J (2014) Heterogeneous mineral assemblages in martian meteorite Tissint as a result of a recent small impact event on Mars. Geochim Cosmochim Acta 140:334-348

Weisberg MK, McCoy TJ, Krot AN (2006) Systematics and evaluation of meteorite classification. In: Lauretta DS, McSween HY (eds) Meteorites and the early solar system II. The University of Arizona Press, Arizona, pp 19-52

Weisberg MK, Kimura M (2010) Petrology and Raman spectroscopy of high pressure phases in the Gujba CB chondrite and the shock history of the CB parent body. Meteorit Planet Sci 45:873-884

Whittaker AG, Kintner PL (1969) Carbon: Observations on the new allotropic form. Science 165:589-591

Whittaker AG, Watts EJ, Lewis RS, Anders E (1980) Carbynes: carriers of primordial noble gases in meteorites. Science 209:1512-1514

Wirth R (2009) Focused ion beam (FIB) combined with SEM and TEM: advanced analytical tools for studies of chemical composition, microstructure and crystal structure in geomaterials on a nanometre scale. Chem Geol 261:217-229

Xie X, Minitti ME, Chen M, Ho-k M, Wang D, Shu J, Fei Y (2002a) Natural highpressure polymorph of merrillite in the shock veins of the Suizhou meteorite. Geochim Cosmochim Acta 66:2439-2444

Xie X, Minitti ME, Chen M, Mao H-K, Wang D, Shu J, Fei Y (2004) Tuite, gamma$\mathrm{Ca}_{3}\left(\mathrm{PO}_{4}\right)_{2}$ : a new mineral from the Suizhou $\mathrm{L} 6$ chondrite. Eur J Miner 15:1001-1005

Xie X, Gu X, Yang H, Chen M, Li K (2020) Wangdaodeite, the LiNbO ${ }_{3}$-structured high-pressure polymorph of ilmenite, a new mineral from the Suizhou L6 chondrite. Meteorit Planet Sci 55:184-192

Xie Z, Tomioka N, Sharp TG (2002b) Natural occurrence of $\mathrm{Fe}_{2} \mathrm{SiO}_{4}$-spinel in the shocked Umbarger L6 chondrite. Am Min 87:1257-1260

Xie Z, Sharp T, Decarli P (2003) Estimating shock pressures from high-pressure minerals in shock-induced melt veins of the chondrites. In: Lunar and planetary science conference, $\mathrm{p}$ 1280.pdf

Xie Z, Sharp TG (2004) High-pressure phases in shock-induced melt veins of the Umbarger L6 chondrite: constraints of shock pressure. Meteorit Planet Sci 39:2043-2054

Xie Z, Sharp TG, DeCarli PS (2006) High-pressure phases in a shock-induced melt vein of the Tenham $L 6$ chondrite: constraints on shock pressure and duration. Geochim Cosmochim Acta 70:504-515

Xie Z, Sharp TG (2007) Host rock solid-state transformation in a shock-induced melt vein of Tenham L6 chondrite. Earth Planet Sci Lett 254:433-445

Xie Z, Sharp TG, Leinenweber K, DeCarli PS, Dera P (2011) A new mineral with an olivine structure and pyroxene composition in the shock-induced melt veins of Tenham L6 chondrite. Am Min 96:430-436

Yagi A, Suzuki T, Akaogi M (1994) High pressure transitions in the system $\mathrm{KAISi}_{3} \mathrm{O}_{8}-\mathrm{NaAlSi}_{3} \mathrm{O}_{8}$. Phys Chem Miner 21:12-17

Yoshida M, Miyahara M, Yamaguchi A, Tomioka N, Sakai T, Ohfuji H, Maeda F, Ohira I, Ohtani E, Kamada S, Suga H, Ohigashi T, Inagaki Y (2021) Elucidation of impact event recorded in the Iherzolitic shergottite NWA 7397. Meteorit Planet Sci. https://doi.org/10.1111/maps.13735 
Zhang A-C, Jiang Q-T, Tomioka N, Guo Y-J, Chen J-N, Li Y, Sakamoto N, Yurimoto H (2021) Widespread tissintite in strongly shock-lithified lunar regolith breccias. Geophys Res Lett. https://doi.org/10.1029/2020GL091554: 2020GL091554

Zhang J, Herzberg C (1994) Melting experiments on anhydrous peridotite KLB-1 from 5.0 to 22.5 GPa. J Geophys Res Solid Earth 99:17729-17742

\section{Publisher's Note}

Springer Nature remains neutral with regard to jurisdictional claims in published maps and institutional affiliations.

\section{Submit your manuscript to a SpringerOpen ${ }^{\odot}$ journal and benefit from:}

- Convenient online submission

- Rigorous peer review

- Open access: articles freely available online

- High visibility within the field

- Retaining the copyright to your article

Submit your next manuscript at $\boldsymbol{\nabla}$ springeropen.com 